\title{
In Search of Traces of the Mandrake Myth - The Etymological, Historical, and Ethnobotanical Roots of Its Vernacular Names
}

\author{
Amots Dafni ( $\nabla$ adafni@research.haifa.ac.il ) \\ University of Haifa https://orcid.org/0000-0002-9841-1662 \\ Cesar Blanché \\ University of Barcelona: Universitat de Barcelona \\ Salekh Aqil Khatib \\ Institute of Evolution \\ Theodora Petanidou \\ University of the Aegean: Panepistemio Aigaiou \\ Bedrettin Aytaç \\ Ankara University: Ankara Universitesi \\ Ettore Pacini \\ University of Siena: Universita degli Studi di Siena \\ Ekaterina Kohazurova \\ University of Sofia Saint Kliment Ohridski: Sofijski universitet Sv Kliment Ohridski \\ Aharon Geva-Kleinberger \\ University of Haifa \\ Soli Shahvar \\ University of Haifa \\ Zora Dajic \\ University of Belgrade: Univerzitet u Beogradu \\ Helmut W. Klug \\ University of Graz: Karl-Franzens-Universitat Graz \\ Guillermo Benítez \\ University of Granada Faculty of Pharmacy: Universidad de Granada Facultad de Farmacia
}

\section{Research Article}

Keywords: Mandragora spp, Plant names, Etymology, Phytonymy

Posted Date: June 12th, 2021

DOI: https://doi.org/10.21203/rs.3.rs-576883/v1

License: @ (1) This work is licensed under a Creative Commons Attribution 4.0 International License. Read Full License 


\section{Abstract}

Background: Mandrake (Mandragora spp.) is perhaps the most famous medicinal plant in western cultures since Biblical times and throughout written history. In many cultures, mandrake is related to magic and witchcraft, which and is said to have a psychosomatic effect (especially when mandrake contains narcotic compounds) in addition to the pharmacological influence, as occurs with other narcotic magical plants. Due to its unique properties and related myths, it is not surprising that this plant has many names in many languages.

Methods: This paper presents an attempt to reconstruct the etymological, ethnobotanical, and historical and folkloristic roots of 296 vernacular names of Mandragora sp. in forty-two languages. We used the plant's morphological data, philology, myths and legends, medicinal properties and uses, as well as historical evidence and folkloric data, to explain meaning, origin, migration, and history of the plant's names.

Results: The names were classified into the following main categories:

Derivatives of mandragora (20 languages), alraun (7) and of yabroukh (5). The salient groups of the plant's vernacular names are related to: Anthropomorphism (33 names in 13 languages); Similarity to other plants (29/9); Supernatural agents (28/9); Narcotic effects (21/8); Leaves, fruits, and seeds (21/8); Aphrodisiac properties (17/10); Use of a dog (15/9); Gallows (14/5); Black magic, sorcery, witchcraft (13/8), and Medicinal use (11/7).

Conclusions: This frequency distribution of the mandrake's vernacular names reflects its widespread reputation as related to the Doctrine of Signatures, beliefs in its supernatural, natural, and mythic powers, and to a lesser extent, its uses in magic and medicine. A spatiotemporal analysis of the mandrake's names supports the old idea that the pulling ceremonies for this plant originated in the Near East and that various other myths related to this plant may have originated in different places and periods.

\section{Introduction}

Gledhill [1:1-2] noted that "Common plant names present language at its richest and most imaginative (sic!).... Local variations in common names are numerous and this is perhaps a reflection of the importance of the plant in general conversation in the kitchen and in herbalism throughout the country in bygone days."

Some names refer unequivocally to a specific plant species (monosemic name), while other names can be used for different plants (polysemic names). The proliferation of names for individual botanical species is related to a variety of factors: the geographical range of the plant and languages spoken in its area, the ethnobotanical value as a ritual and/or medicinal plant, its strange appearance or resemblance to familiar objects, etc.). Similarly, Pistacia terebinthus $\mathrm{L}$. has a variety of names throughout Greece, which probably reflects the importance of the plant for the local societies [2, 3]. Functionality, however, is no guarantee of name diversity. Consider the olive tree, which in the Mediterranean is both omnipresent and widely used yet is known simply as the "olive tree." On the other hand, some plants' names are quite similar in the different languages of the places where they grow, for example, Potentilla reptans L. is called "five fingers herb" (or names containing the words "five," "fingers," "hand" or "foot") in English, French, Spanish, Portuguese, German, Russian, Greek, Romanian, Polish, Lithuanian, Catalan, Basque, and Chinese, due to the leaf morphology [4]. In Serbian, "petoprsnica", literally meaning "of five fingers".

A few studies have conducted a multilingual comparison of the same plant species to understand its performance, perception, and use across its area of distribution. Flattery and Swartz [5:141-152] study the identity of the mythical "Haoma" plant, which plays an important role in Zoroastrian worship. In addition to historical-geographic analyses, they employ a multilingual comparison of the common names of Peganum harmala L. (and other plant species suspected of being "Haoma"). Linguistic analysis is used by these authors as another tool to establish the plant's identification. A similar approach is adopted by Šeškauskaitė and Gliwa [6] when studying the etymology of Datura stramonium L. and related narcotic species in Lithuania. Austin and Felger [7] study the etymology of the genus Fagara (Rutaceae), from its first written record in the eleventh century through to the present day. They employ historical, economic, geographic, linguistic (in several languages) and ethnobotanical approaches to understand the origin of the plant and its economic trade route. Austin [8] studies the history and etymology of Sambucus to reveal the history of the intercultural exchange of this plant and the evolution of its name. Dafni et al. [9] reconstruct the etymological, ethnobotanical, and folkloristic roots of 290 vernacular names of Ecballium elaterium (L.) A. Rich. in 38 languages. They use the plant's morphological data, ecological characteristics, medicinal properties and uses, as well as historical evidence and ethnobotanical data, to explain the meaning, origin, spread, and history of the plant names.

Mandrake is perhaps the most famous medicinal plant in western culture since Biblical times and throughout written history. This view has been clearly expressed by several authors, with statements such as: "Of all the medicinal herbs used in the ancient and medieval world, none was regarded with as much fear or wonder as the mandrake"; Silberman [10:89] noted that "Of all the plant illustrations (in medieval herbals) representing mythological beliefs, superstition, or witchcraft, the one that comes uppermost to mind is the mandragora or mandrake."

Moreover, several well-known writers have devoted passages to the plant and its properties, from William Shakespeare's many plays (see [11]), including Othello, Macbeth, and Romeo and Juliet (e.g., "And shrieks like mandrakes torn out of the earth" Act IV, Sc. 3), to Niccolo Machiavelli's La Mandragola, the Nobel Prize-winner C. J. Cela's Diccionario del Erotismo, and the recent and popular J. K. Rowling's Harry Potter and the Chamber of Secrets.

\section{Aim of the study and hypotheses}

Waniakowa's [12] survey of the mandrake names is limited to linguistic aspects mostly of northern and central European languages and deals especially with the comparison of the common names with those of Atropa belladonna L. She relies extensively on ethnobotanical information to elucidate the meanings of these plant names in Europe Most of this geographic area is beyond the mandrake's natural distribution, i.e., mainly the Mediterranean area spreading eastward to Iran and the Caucasus. 
In the present study, we cover a larger geographic area and more languages in search for mandrake names. We use the plant's morphological data, ecological characteristics, medicinal properties and uses, as well as historical evidence and ethnobotanical data, to explain the meaning, origin, spread, and history of the plant's names. The study was done to pinpoint the putative geographic origin and cultural distribution of the myths related to the mandrake based on the distribution and the origin of names throughout history. Our working assumption is that a proliferation of mandrake names in any specific language or category (see below) may reflect its ritual and/or practical importance and/or intimate knowledge related to this plant (see above; [1:1-2]). Based on our analysis, we examine four hypotheses:

\section{Hypothesis 1}

Due to the longer history and broader distribution around the Mediterranean (including the Middle and the Near East), one expects to find more cultural migrations of names (and myths and customs reflected in these names) from east to west (Middle East to Europe) and from south to north (southern Europe to eastern, central, and northern Europe) than migrations in the opposite directions.

\section{Hypothesis 2}

One expects to find more plentiful names (and in more categories, see below) in countries in which the mandrake is native (especially around the Mediterranean) and has more ancient history than in other parts in Europe in which the mandrake (and its legends) arrived later. This would particularly relate to the appearance of the plant (e.g., morphology of aerial parts, root, fruits) and their similarity to other plants and animals including humans, and to its uses and effects.

\section{Hypothesis 3}

Since the mandrake has a long history as an aphrodisiac and as an omnipotent medicinal plant over generations (see [13]), one expects to find relatively many names which are related to these categories.

\section{Hypothesis 4}

Witchcraft and black magic were highly developed in Europe [14;15]; and involved hallucinogenic and narcotic plants [16:passim], while in the Muslim world they are strictly condemned [17:1356;18:passim;19:passim]. Thus, one expects to find more names related to this category in Europe than in the Muslim world.

\section{Materials And Methods Data gathering and possible pitfalls:}

Popular names for Mandragora spp. (see below) were collected in as many languages as possible through: field interviews, the authors' personal knowledge, dictionaries, literature, and internet sources (especially sites with photographs which enabled a visual verification of the plant's identity). All the names were checked by us as well as by local botanists to ascertain their validity as well as their meaning in each language. Dubious or wrong names not clearly related to Mandragora were discarded.

We include all the names for the genus Mandragora. This approach was taken for several reasons: 1. The distinction between M. officinarum L. and $M$. autumnalis Bertol. is debateable even among specialists [20-23]. We have not found any traces of distinction between the vernacular names of these two species. 2. A significant amount of European mandrake descriptions and iconographic depictions, mainly in late Medieval, Renaissance, and Baroque times, refer to a distinction between male and female plants, known as foemina (female) or mas (male) mandrakes. This distinction seems to be more or less arbitrary, and while some authors, e.g. [24] suggest that plants with ovoid fruits (more abundant in Central and Eastern Mediterranean, and attributed as $M$. officinarum) are considered as "male" mandrake, whereas plants with spherical fruits (more abundant in W \& S Mediterranean and attributed as $M$. autumnalis) are considered female, others (e.g. [25]) point to a direct association with the Mediterranean recognised species: the Greeks' male mandrake for M. officinarum, and female for M. autumnalis. This distinction seems to be a mental, intellectual, scholarly construction, as the mandrake plants of both species are biologically hermaphrodite. No true vernacular names allude to the gender of mandrake plants. 3. The Iranian-Caucasian species ( $M$. turcomanica Mizg.) shares, largely, the same medicinal uses as the former two species, which indicates a large-scale cultural migration between the Mediterranean and the Irano-Turanian species ([13]) as well as many rituals (see below). Secondary sources (e.g., [26-31]) were scrutinized as carefully as possible for the validity of the mandrake names by comparison to the original source publications in each language and personal knowledge of the authors.

Considering the validity and reliability of the names used for mandrake in the various languages, we tried to look out for, and avoid, the following possible pitfalls:

1. In several countries in which the mandrake is not native (e.g., Northern, Central, and Eastern Europe), there is a tendency in the literature to adopt and to translate the mandrake's names from other languages (especially from Ancient Greek and Latin as well as from the Arabic). Authors just translate old literary names into their own languages, while these names were practically not used in the vernacular. This discrepancy is obvious when botanical texts are compared to folkloric/literary ones.

2. It is worth paying attention to distinguish between names that were given to the mandrake in its natural distribution in comparison to countries into which it was introduced (as a garden plant and as medicine, for ritual, and/or witchcraft purposes). It is supposed that the history of the plant names in these countries is shorter and may reflect later local beliefs and traditions. 
3. Several sources used the name "mandrake" when the botanical identity is that of species of other genera such as: Atropa (rev. [12]), Bryonia (see [32:111; 33:193; 11:144], and Podophyllum [34: 35:495]. Also, less frequently other species such as: Datura stramonium L., Valeriana officinalis L., Aconitum tauricum Wulfen, Gratiola officinalis L., Hyoscyamus niger L., Leonurus cardiaca L., Cicuta virosa L. and Peganum harmala L. [36:3-4], Chelidonium majus L. [37:273], Allium victorialis L. [38:120-121] and Tamus communis L. [39:204] were named "mandrake."

Thus, it is not surprising that Eliade [40] in his famous article "The Cult of Mandragora in Romania" referred to Atropa belladonna L. as "mandrake" and not Mandragora officinarum (that was previously in the genus Atropa, which is not indigenous to Romania). As a result, since several authors cited Eliade's work (e.g. [41-44]), Atropa belladonna was related to Mandragora.

4. In the literature, several times a name is given from a certain language as a proper name from a different language. For example, the mandrake names antropophora and xērà ánthē are regarded as "Latin" names as in the consulted works (Dioscorides' Materia Medica [45]) are considered so, but these have been directly transcribed to Latin from Greek, and these names are probably better considered as just Greek names and were omitted from our analysis.

5. In the same sense, in some territories, a certain name may have arrived not as a vernacular name but with migrants, sellers, or any citizen (coming from the same territory-language as the visitor), or from the medical literature, together with medical texts. In these cases, names could be better interpreted as a cultural migration and not as a vernacular name. An example is the name mandragora in Catalan. Once it is explained that the origin of this name is more probably Greek than Latin, and since Catalan is a Romance language, it seems that the very first references recorded in Catalan in the thirteenth-to-fourteenth centuries (firstly: mandrágola; secondly: madragora; see [46]) come from originally Arabic contexts and are later inserted in medical (official medieval medicine) texts. The reference to "mandrágola" is even earlier than "mandràgora" and comes from the first scientific texts written in Catalan.

\section{Data presentation}

Spelling variants of the same name were pooled into the same cell in the tables and counted only once. To avoid repetition, we cited each author only once in the relevant cell even if he presents several spelling variants. This method had no influence on our conclusions. Sometimes, especially with respect to alraune in German, distinguishing between a "derivative" (i.e., derivatives from a generic name, as mandragora or alraune) and a "spelling variant" (e.g., mandracola instead of mandragora in Spanish; about sixty variations are scattered in the literature; see Table 1), is quite arbitrary. The same is the case with regard to transcriptional corruptions of Farsi and Arabic names in European languages (e.g., abrusanam and yabroukh).

The names were grouped, in the light of linguistic and ethnobotanical aspects, into the following categories: A. Derivatives of "generic" names (with their variants in transcription): 1. Mandragora; 2. Alraune; 3. Yabroukh. B. Morphological characteristics: 1. Root (Anthropomorphism); 2. Leaves, Fruits, and Seeds; 3. Similarity to other plants. C. Pharmacological characteristics and medicinal uses: 1. Medicinal properties; 2. Narcotic; Hallucinations; Poisonous; 3. Aphrodisiac. D. Magic and witchcraft: 1. Black magic - sorcery, witchcraft, and magic, Bad luck, Evil eye; 2. Evil supernatural agents, Satan, the devil, genie, monster, dragon. 3 White magic - Good luck, talisman, dolls. E. Pulling-out ceremonies: 1. Screaming, groaning and voices; 2. Use of a dog; 3 . Shining and lights; F. Plant conception: Gallows and hanging: 1. Plant originated from human semen, urine; 2. Creation of Adam. G: Relationship to historical and mythological characters: 1 King Solomon, Circe, and Prometheus; 2 Elephant. NC: Not classified. There are other names whose meaning/origin is not clear, or they are not related to any of the above-defined categories. A very few names (e.g., Mandragora mannetje ["Mandrake man"] and pisduiveltje ["Little piss devil"] in Dutch) may be classified into two categories. In these cases, we decided on the category according to relevance in the original text.

\section{Results}

Our database with 296 names for the plant covered, as mentioned, a total of forty-two languages spoken from antiquity to the present day in the area where Mandragora officinarum (including M. autumnalis) is widely distributed and/or used. This includes two dead languages (Latin and Old German). There are nine languages for which more than ten vernacular names for mandrake were recorded (see Table 8; Figure 1). It is somehow surprising that four of these nine languages are not from the territory in which the plant is native (German, Dutch, English, French), and that at least in one more (Serbian) the plant has been considered extinct [47], while in Greece, Arabic countries of North Africa, Spain, and Turkey, it is currently wild [22]. These nine languages cover 74\% of all names, while the remaining thirty-three languages represent $26 \%$ of names.

\section{Discussion}

\section{Derivatives of "generic" names}

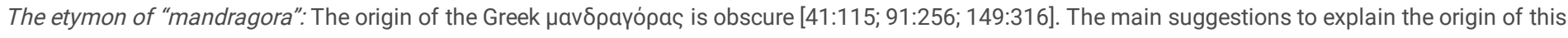
name are as follows:

1. Persian origin from mardum-giyah (plant-man) [41:115; 208:237]. This idea is rejected by Asatrian [100] based on the arguments that this plant has no name in old Persian texts and because in the historical period it was already an extinct (or sporadic) species within the floristic nomenclature of Iran.

2. Greek origin: 'mándra'= "stable" and 'agora'= "gathering place" thus referring to the places where it was commonly found [209:302; $120: 1835]$; although this explanation was refuted by Genaust [208:237].

3. Greek origin: 'mandragoros'is derived from 'mándra' = "an oxtail," sometimes relating to cattle, and 'aguros', cruel, on account of its poisonous effect on cattle [210, II:132; 211:355]. 
4. Greek origin: may be a variation of the Greek 'mandragoritis,'an alternate name for Venus [79:20; 212:3; 122:260; 176:241]. This idea was refuted by Genaust [208:237].

5. Sanskrit origin: a. 'mand'= "joy," "intoxication"[91:256].

6. Sanskrit origin: b. 'mantasana'= "sleep," "life," or 'mandra'= "pleasure" [91:256].

7. Sanskrit origin: c. 'mantara'= "paradise tree" and 'aryu'= "unmarried, violently passionate" [91:256].

8. Sanskrit origin: d. 'mandros'= "sleep" and 'agora'= "substance" [176:241; 149:316] (see also [213:22-23]).

We found $\mathbf{2 5}$ names in $\mathbf{2 1}$ languages in which the plant is called mandragora and/or its derivatives.

Most of the variants were in Greek (8) and in Italian (6), and most of the derivatives are from European languages (except one in Turkish and one in Georgian). We consider this as an indirect evidence for the European (Greek) origin of the derivatives of this name (Table 1). It seems that this is a kind of indirect evidence for the Greek origin of this name, as stated in, e.g., the Dictionary of the Real Academia de la Lengua (Spanish; [214]).

Asatrian [100]) analyzed the Farsi names and concluded that the origin of the name mandragora is Greek and not Iranian.

The etymon of "alraun": Mandrake in modern German is known as 'der Alraun' or 'die Alraune,' which indicates the idea of a male and a female of the plant by referring to the shape of the root (two roots: female; more than two roots: male [215:34]). The first occurrence of the plant name occurs in a 10 th $\mathrm{c}$. gloss of the biblical dudaim or else mandragora [30:21; 142:327]. The name in Old High German is 'al-rūna,'which transformed to Middle High German 'al-rûne,' which then became the Early and Modern High German Alraun(e) [216]. The German name is composed of the prefix 'al-'and the stem 'rune'. All etymological explanations of the name are highly speculative [215:34], but all try to surpass each other in adding mystery to the history of the plant name. There are several theories on its origin:

1. The name might be associated with the seeress Albrûna (Lat. Aurinia), who lived during the first century

and is documented in Tacitus's Germania [30:22]; the theory is labeled highly unlikely [215:34]. This theory can be found in Grimm [217, I:404-5], who relates that the names alrūne/alrūn (and the Nordic Aelfrûn, [215:34]), to be identified with a wise-woman of the (Teutonic) antiquity from its old sense of a prophetic and diabolic spirit, has at length passed into that of the root (mandragora).

2. Etymologically the word-stem '-rune' can denote "to murmur, to whisper magic words," or "whisper secrets, talk, spell" [30:21; 215:34].

3. The prefix 'al-'can either be related to the historic forms of 'Alb' ('incubus') or 'all, groß'('all, mighty').

Combinations of these word parts suggest that the name means either "whispers/secrets of incubi," or "knowing all magic," or "mighty secret" [208:237; 215:34]. Referring to the highly uncertain etymology of the name, Kluge [215:34]) also but hesitantly suggests the meanings "highly cleft" or "covered with wrinkles" as possible etymological interpretations.

We found 9 names in $\mathbf{7}$ languages in which the plant is called alraune and/or its derivatives. Most of these occur in different German variants (32); two variants are in Serbian and the rest are Scandinavian languages.

The etymon of "yabrouh": The biblical (Genesis 30:14-16; Songs of Songs 7:14) "वसाuा" ([Duda'eem]) was translated into Aramaic by Onkelos (35-120 BCE

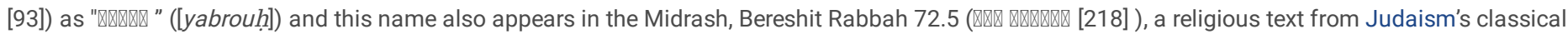
period, 3-5 ${ }^{\text {th }}$ c.) and the Talmud (4-5 $5^{\text {th }}$ c. BCE, Sanhedrin 99b; Erubin 10:26a [93]), as one of the names of the mandrake. This interpretation is accepted by the common Aramaic dictionaries (e.g., [219:562; 220:234; 221:329; 222:197]) as well by the most important Jewish Bible commentaries (e.g., Avraham Ben Meir Ezra (Ibn Ezra), 12 ${ }^{\text {th }}$ c. [223] and Mōšeh ben-Nāḥmān = Ramban (Nachmanides), 13 ${ }^{\text {rd }}$ c. [224]). Although some other identifications for duda'eem have been suggested, e.g., by Rashi (Shlomo Yitzchaki 1040 -1105) in his authoritative interpretation of Genesis, they are not accepted by later authors (e.g., [225:323$325 ; 186$, III:363-368]).

While there is general acceptance concerning the botanical identity of the "yabrouh" as mandrake, there are several debatable interpretations concerning the etymology of this name, as follows:

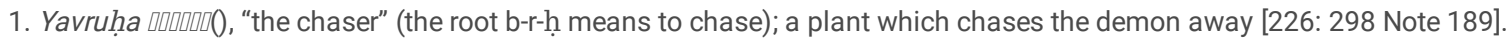

2. According to Wetzstein [227:441] [jebrûah] means "it (only) needs life." This is equivalent to saying that the root is so like a human body that it only needs to have a soul breathed into it to become a small human being. The author relates this name to the Farsi [medumgiâ] = "the plant man."

3. Ascherson [191:890] mentions that today's name for mandrake in Syria is [ĝerâbûh], which is likely an intentional corruption of the literary Arabic name [jabrùh], which would not provide the Syrians with a suitable meaning, whereas bûh, the final syllable of [ĝerâbûh], denotes sex drive, and thus the word can be given the meaning of "aphrodisiac," as indeed the mandrake fruits were considered to be (in Genesis 30,14 ) and still are today.

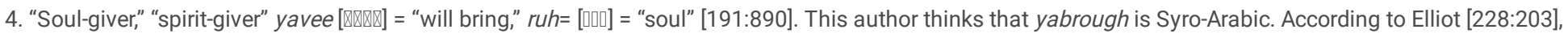
Aramaic yahb-rouh $=$ giver of life.

5. Nathan Ben Yeshaya (Yemen 14 ${ }^{\text {th }}$ c.) explains: "yabroukh, since its nature is that the one who pulls it out will lose his spirit" [229:151].

Page $5 / 42$ 
6. According to Ibn Sina, "'jabrol" (a derivative of yabroukh) is the root of the mandrake and could be a name for any natural object, for instance a growing plant, in human shape (Ibn Sina, Canon of Medicine, Lib. II, Trsacii, Cap 365; cited by [230:70].

7. Fleisher and Fleisher [231:245] suggest that [yabruf] comes from Arabic [yâ-abu-er-ruh], which means "O master of breath," (but in Aramaic it is the opposite meaning; see [232:169].

We found 8 names in 5 languages in which the plant is called [yabroukh] and/or its derivatives. Its derivatives appear only in Arabic (6), Aramaic (3), and Bengali (1). The Farsi name [sāyeh-borūj] may also be related to this group.

\section{Names related to the plant's morphological characteristics}

Names related to morphological characteristics are the most frequent ones in all languages (up to 81 names within this category, $27 \%$ of total names, see Figure 2), especially those connected with the root form and the similarity with other plants.

Root: Mandrake is a classic exemplar of the "Doctrine of Signatures": this could be stated as form recapitulating function-physical characteristics of plants reveal their therapeutic value [233:256]. The root resembles the human form (anthropomorphic) - symbolically, it is equivalent to the "root" of the human being, sexuality, and further, to fertility [11:144] and love philtres [234, II:715].

Schultes and Hoffmann [117:185] suggest that the European fear of the mandrake during the Middle Ages was due to Doctrine of Signatures. It was Pythagoras (in Dioscorides Materia Medica I.570 [45, I.570]) who gave the name anthropomorphos (which means "shaped like a man," av $\theta \rho \omega \pi 0 \mu \circ \rho \varphi \circ$ ) to the mandrake. It is not surprising that $\mathbf{3} 3$ names in $\mathbf{1 3}$ languages are connected to the similarity of the mandrake's root to the human body, of which $\mathbf{7}$ are in German, 6 in Dutch, and 4 in French. Thus, the anthropomorphic view of the mandrake, as reflected in its names, appears especially in western European languages.

Leaves, fruits, and seeds: Few names are related to the shape of the leaves of the mandrake such as: loshtak ["ear"] in Armenian, ["five-veined plant"] in Turkish, and papútsa ["shoe-shaped leaves"] in Greek. These names are also related to other plant species. The Arabic name [š'bysk] originated from Farsi šā(h)- "black" (cf. šāh-tūt) and bīzak "seed, grain," meaning "(a plant with) black (dark) seeds." Isidore of Seville (Archbishop of Seville, c. 560 - 636 CE) wrote [84:351]: "Mandrake (mandragora) is so called because it has a sweet-smelling fruit the size of a Matian apple; hence Latin speakers call it "apple of the earth." 19 names in 7 languages denote the resemblance of the mandrake to the apple. Many other names, such as ["dog's apple,"] and ["Devil's apple"] are assigned to other categories.

Similarity to other plants: Although the mandrake is a well known and very distinctive plant, sometimes its name refers to another plant. This could be because the other plant is better known locally, usually because it offers big, edible fruits (such as names related to apples, tomatoes, or even loquat). Such names are, e.g., ["wild tomato"] in Italian, ["eggplant"] in Spanish and Arabic, and ["earth loquat"] in Turkish. Conversely, we should mention here that the name "mandrake" has been also used for other plant species (see Introduction).

\section{Names related to the plant's uses}

Medicinal properties: Mandrake (Mandragora spp.) is perhaps the most famous medicinal plant in western culture since biblical times and throughout written history. This view has been clearly expressed by several authors, with statements such as: "Of all the medicinal herbs used in the ancient and medieval world, none was regarded with as much fear or wonder as the mandrake" [235:189]). Harrison [171;91] mentions that the plant's medicinal virtues appear to have been discovered at a remote point in the development of ancient cultures, and although magical and superstitious beliefs tended to accompany its use, it seems clear that the narcotic qualities of the mandrake were appreciated through the entire period of its usage. Therefore, it is not surprising that "there is no medicinal plant known around which cluster more mysterious and quaint associations than around mandragora" [236:6]. Mandrake was considered a panacea, especially in the Middle Ages [237]. In Wright's [238:182] words, "Mandrake is a cure for all except death."

Thus, it is not at all surprising to find $\mathbf{1 1}$ names in $\mathbf{7}$ languages. Eleven names reflect the importance of the mandrake as a panacea down the generations. It is noteworthy to mention the names ["Father of health"] in Arabic and Turkish, and ["Doctor's plant"] in German. The Armenian name ["King of all grasses"] deserves special attention. Arakelova [101:153] mentions that in the Armenian folk tradition, the mandrake is "the king of all plants." Its obvious sacred meaning among Armenians and its high estimation as a real panacea is proved by the existence of a special prayer-praise called Ayot'k' vasn loštakin, ["the Prayer to the mandrake"] [239:285-286] "You are the king of all the plants! / Almighty God created you and endowed you / With talent the of healing of people and nations / From all known illnesses in the name of the Invisible and eternal God..."

Three names of the mandrake indicate specific medicinal uses of this plant. The Greek names fistulóriza and fistulóchorto mean ["Fistula-healing root"] as mentioned by Hippocrates [240:822] (inflamed fistulae); $4^{\text {th }}-3^{\text {rd }}$ BCE. The Turkish name kankurutan, ["Blood dryer"], reflects this use as indicated from SyriaIraq: $12^{\text {th }}$ c. [144, II: 334] for "Flow of the blood" and from Turkey [241:2011] ("Stops fever of the bile and blood").

Narcotic, hallucinogenic, poisonous: Hyoscyamine and scopolamine (or hyoscine) stand out among the major tropane alkaloids in mandrake [242], although several other alkaloids are present $[243,244 ; 245 ; 231 ; 246 ; 247]$. These tropane alkaloids are antagonists of muscarinic receptors (thus, with parasympatholytic effect), and have been described as having psychedelic and hallucinogenic properties. In higher doses, they may cause chronic spasms, a strong heartbeat, tachycardia, dilation of the pupil, inhibition of salivation, respiratory arrest, and coma. Therefore, mandrake was regarded as extremely hazardous to the level of being a mind-altering substance [242].

These widely known effects (narcotic, hallucinogenic, and poisonous) are reflected in $\mathbf{2 1}$ names in $\mathbf{8}$ languages. Out of these, six names are related to the somniferous effect of the plant and eight to madness. The rest are related to poisoning, intoxication, and causing of death.

Page 6/42 
Aphrodisiac: The reputation of mandrake as an aphrodisiac first appeared in biblical times (Genesis 30: 4-16). It was noted by Theophrastus in the $3^{\text {rd }} \mathrm{C}$. BCE $[61, I X, 8.8]$ and was widely expanded and iconographically depicted and transmitted in the medieval period, with reference mainly to the fruits [24]. Benítez et al. [13] found that this use was popularized in the last century and remained in the tradition with limited citations throughout history. A possible explanation has already been pointed out: "the fruit of the mandragora became a symbol of love" [248:90], but not for actual use. Hanuš et al. [244] found no fewer than 136 chemical compounds in the mandrake fruit, but none of them is known to have an effect on human sexual behaviour. They conclude: "The main compounds found in the ripe fruit and undetected in the unripe fruit are likely to be responsible for the fruit's special taste and odour and its so-called aphrodisiac qualities." Therefore, although mandrake's aphrodisiac properties have never been pharmacologically proven, still today the fruit is eagerly sought for this purpose throughout its distribution range (especially in the south-east Mediterranean and the Balkans) (Benítez et al. [13]). Nevertheless, the profound profound of the Bible as well as local traditions are so deep rooted in many cultures that no less than 17 names in 10 languages are related to love (especially "love apple or berry" (3) and "love plant or herb" (5), or other love-related attributes (e.g. ["the fruit that gets the lovers close"] and ["the dependent bride"] in Arabic). The relatively low number of names relating the mandrake to love and as an aphrodisiac ( $5.7 \%$ of total; see Figure 1$)$ reflects its rather rare use for this purpose down the generations (see [13], for a review).

\section{Names related to the plant's mythology}

Black magic - sorcery, witchcraft, and magic, bad luck, and evil eye: Mandrake is probably the most celebrated of all "magical" plants in history and has thus given rise to a mammoth literature [12:161; 249:110; $250: 94]$. The magical powers ascribed to the mandrake, both benign and evil qualities, made it an object of awesome veneration. In the folk imagination, the mandrake was conceived as a being with obvious ties to underworld forces [100:105; 101:153]. In many cultures, the mandrake has a notorious reputation as a plant used in black magic and witchcraft [251:532]. In the Middle Ages, the mandrake was an indispensable element in the witch's cauldron [44:112; 109:71]. Because the root has an uncanny resemblance to human limbs, the mandrake was considered half demon [252:3], with great magical properties [253:71].

The mandrake contains narcotic and hallucinogenic compounds which have the ability to heal, to injure, to cause madness, to induce a shamanistic trance, or to kill $[117 ; 171 ; 179 ; 254]$, as is the case with other narcotic magical plants $[27 ; 255 ; 256]$. The ultimate result is that mandrake has a role in magic [142; 200 ; 236] and witchcraft [179; 257:166], especially during the Middle Ages [77]. Most famous was its use in witches' flying ointment during the Middle Ages [29, II:342; 182; 257:166; 258:passim]. Witches' activities are inseparable from demonic/devilish/Satanic worship; thus, the distinction between names related to witchcraft and those related to the devil/Satan is made from a purely technical viewpoint.

In our analysis we recognize three subcategories related to this wide issue. Thirteen names in eight languages were found related to black magic and witches and witchcraft such as ["sorcerer's root"] in English and Russian and ["magic root"] in Estonian, Dutch, and German. Four names are related to witches: (["witches' herb"] in Dutch, English, and German, and ["witches' love root"] in Dutch. All these names related to witches are from European countries which are beyond the natural distribution of the mandrake.

Evil supernatural elements - Satan, devil, genie, monster, and dragon. Hildegard von Bingen (1098-1179) states: "The mandrake takes on and holds the influence of the devil more than other herbs because of its similarity to a human" [259:33]. According to Thompson [252:66-67], the narcotic effect of the mandrake, which may also cause death, is the reason for the plant's association with the devil or an indwelling demon. In some places (such as England), it was still believed in the nineteenth century that the devil/Satan was perpetually looking on [180:60].

Many authors discuss the relation between the mandrake and the devil/Satan $[29,11: 346 ; 33 ; 260]$. The mandrake legend was at its height during the fifteenth, sixteenth, and seventeenth centuries, a period during which belief in the devil acquired an intensity and an immensity of scope unknown before or since [122:268]

Twenty-eight names in $\mathbf{9}$ languages were connected to various supernatural agents due to the narcotic and hallucinogenic effects. Nine names include the devil (e.g. ["devil's plant"] in Dutch, ["devil's apple"] in English, German, and Hungarian; ["devil's food"] in English and Dutch); 8 are related to various demonic Muslim figures (mainly goula, jinn), to Satan (e.g. ["Satan's testicle"] in English, ["Satan's apple"] in German, ["Satan's turnip"] in Turkish), and three names include the word dragon: ["dragon's apple"] in Dutch, ["dragon's puppet"] in German, and ["dragon's doll"] in English. Six names refer to various other evil agents, (e.g. ["little imp-man"], ["demon's root"], and ["demon's herb"] in German, ["goblin"] in Greek, and ["ghost's apple"] in Turkish). It is noteworthy that while black magic and witchcraft names are restricted to Europe, the various other demonic figures appear in almost all the distribution range of the mandrake, probably as a result of its narcotic effect that was considered to be caused by supernatural evil, in addition to the "demonic" human-like root shape.

\section{White magic - good luck, talisman, and dolls:}

The mandrake root was carved into human-like puppets or dolls which were highly regarded as omnipotent talismans [29, II:343-344; 56:54-64; $122: 26$; 200:406; 201:126-127]. The virtues ascribed to these dolls are not always the same: some act as love charms, others make the wearer invulnerable. But they all have two properties in common. They reveal treasure hidden underground and relieve their owner of chronic disease [122:267]. These dolls were carefully treated, dressed in expensive clothes, fed (with food and wine), and were kept in special boxes with great tenderness [29, II:343-345; 217, 4:1674; 261, II:726; 262, III:487]. Germans formed little idols from mandrake rootsand consulted them as oracles [180:293]. In German folklore, mandrake came to be identified with the alrune, a devilish spirit and a magic root in human form who, when questioned, reveals all secret things touching welfare and increases possessions, enriches, removes all enemies, brings blessing on wedlock, and doubles every piece of coin laid under her [122:262].

Few names are related to the positive fabulous powers of the mandrake doll/root which were used in white magic. According to De Cleene and Lejeune [29, II:343], the German names Geldmännchen ([“money manikin”]) and Glücksmännchen ([“good luck manikin”]) reflect its ability to double money [29; 217, I:94; 263:282]. In German, ["little money-man/money mannikin"] and ["little fortune-man/good luck mannikin"] echoed the ability of the 
mandrake to double money [142:329; 201:111]. Two other German names, ["house father"] and ["heinzelmannchen”] refer toa legendary creature resembling a tiny old man who lives in the depths of the earth and guards buried treasure; a gnome, while ["house's father"] in German denotes the mandrake as a keeper of good luck. The French name ["singing plant"] even while not explicitly mentioning a doll, is also related to the miraculous positive powers of the mandrake. In France (nineteenth c.), the mandrake was thought to have the ability to sing, and its song had the magical potential to endow the alchemist with powers of transformation...just like the philosopher's stone [264:240-241].

Pulling-out ceremonies and supernatural phenomena: The andromorphic shape of the mandrake's root caused it to be considered a semi-demon; thus, it screams while being pulled out and may cause death. This is the reason why a dog was used and why there was the need to close the ears [252:3]. The pulling out of the mandrake, which is related to its supernatural evil powers, is threatened by revenge from these powerful agents [180; 201:124-125; 212:17$18 ; 252: 153]$. This is the very reason why special ceremonies needed to be performed before and during the digging out of the mandrake to pacify these elements. Otherwise, they might immediately kill the herb collectors ("rhizotomies") if they did not take the proper precautions to avoid the expected dangers as stated above. The main elements of the ceremony are special incantations, prayers, and dances, and the use of a dog.

The first to mention the use of a dog while pulling mandrake is Josephus Flavius (first c. CE [265]), provided that the plant name he mentions, "ba'aras," really is the mandrake, as it is agreed to be by most authorities (e. g. [186, III:368]). According to Josephus (Jewish Wars VIII:6. 3), the dog dies immediately. The dog is mentioned again in relation to mandrake pulling-out ceremonies in Iran in the sixth c., Iran [111:2], Syria, twelfth c. [144, II:708-710], Uzbekistan (today's borders), thirteenth c. [41:116], Andalusia, thirteenth c. (under the name ["dog killer"] [125]), Hindustan, fourteenth-fifteenth c. [154, 6, footnote 4], Dagestan, sixteenth c. (M. turcomanica) [198:409], Armenia, eighteen c. [266:99] and again in Iran [267:13] (period not given). The dog was used as a scapegoat to avoid the danger of immediate death caused by the voices that the plant produces. The Avars of Dagestan (northern Caucasus, Dagestan) call this herb xlapuleb xer [lit. "barking grass," "grass (causing) barking"] [184:1486], cited by [102:250]. The author also points out that the Avars call their witches simply xlapulel ruččabi, ["barking women"], since the witches bark during the digging ceremony (ibid.: 251-2). In the Yezidi folk tradition, to avoid death, the soil must first be dug around the root, after which a hungry dog or a goat is tied to it [101]. The first record of using a dog in Europe appears in the sixth c. in the famous illustration of the Codex of Anicia [142:69] and later only from the twelfth c. onwards [142:69; 201:380]. Our survey includes 15 names in 9 languages which relate mandrake with a dog.

Ten names (e.g. ["dog's apple"] in Dutch, French, German, Greek, Italian, and Turkish; ["dog's testicle"] in Turkish, include "dog" , while four of the names (["dog killer"] in Arabic, ["dog uprooter" = dog killer], ["dog killer"], and ["dog breaker"] in Farsi) ) explicitly express the fate of the dog in the ceremony. While the general names are mainly from Europe, the four specific names are in Arabic and in Farsi. This list, combined with the literature on the role of the dog in the ceremony from Iran and adjacent countries, strongly sustains the view that the use of a dog in this ceremony originated in this region.

It is commonly stated in the literature that when being pulled out, the mandrake will let out a scream and the dog will die (cf. [54:46; 252:168-170]). An erudite analysis by Van Arsdall et al. [142:317] shows that the screaming element only reached Europe from the twelfth c. In the first record of a mandrake pulling-out ceremony in the Middle East from Josephus Flavius [265:VIII:6. 3] ( $1^{\text {st }} \mathrm{C}$. CE, Transjordan), there is no mention of a scream. A Syrian-Jewish story composed in Damascus in the twelfth-thirteenth centuries [217:14] mentions the scream. The belief in the screaming mandrake still exists in and around Iran. For example, in northwest Iran there is a belief even today that the mandrake "groans" [268:54-65]. In Armenia, in the eighteenth century, it is mentioned that the mandrake "moans with a human voice" [266:99]. In the Yezidi folk tradition, the mandrake supposedly shouts so shrilly that one who digs it up dies at once [101:153].

We found seven names related to the scream (Tables E1, 1), all of which are from Europe, particularly Poland, where mandrake was widely used in witchcraft to prepare flying ointment, mainly during the sixteenth-seventeenth c. [182:180]. Mandrake does not grow in Poland, and both the term and the folklore attached to $M$. officinarum have been applied to local herbs, usually Atropa belladonna L., deadly nightshade [12:passim; 182:194-195]. Anyhow, it is not at all clear why mandrake was so tightly related to the element of the scream in Poland. The first records about the screaming mandrake appear simultaneously in Europe and the Middle East in the twelfth c. The prevalence of this belief in northwest Iran and Armenia nowadays may serve as indirect evidence for its origin in this part of the world. Rahner [199:214] assumes that the scream was imported from Arabic or eastern sources without giving any references.

Mandrake may shine and produce lights: the first to mention the burning mandrake was again Josephus Flavius [265, VIII:6.3] provided that we accept the general agreement that his plant named "ba'aras" is the mandrake (see [186, III:365]). In the Herbarium, Apulenius Platonicus (4" C. CE; see [269:39]) states: "it [the mandrake] shineth at night altogether like a lamp." The Arabic name sirag al kutrub is usually translated as ["the devil's candle"] [189, I:49: 190:250]. Al Baithar [88:14] wrote, "this medicine (the mandrake) is called sirag al kutrub and is like a torch at night ... the cortex of the root (is like) fireflies which glow at night...it looks like a fire." Richardson [189, l:49] explains: "The devil's candle, on account of its shining appearance in the night, from the number of glowworms which cover the leaves." Another Arabic name, ["the burning mandrake"] corroborates this tradition. Roger [270:47] visited the Holy Land in the seventeenth c. and reported that the mandrake emits sulphurous vapors and glows at night. Stories of the shining mandrake are frequently repeated by European sources (e.g. [142; 190;250; 271:144; 272:330]). Arakelova [101:153] mentions that the Yezidis believe that at night mandrakes glitter and their leaves look like silver. So, this ancient belief still survives to this day in Iran and Armenia.

Thief, gallows, semen, and the mandrake: The belief that the mandrake grew under the gallows from the semen of hanged victims [142; 195:59-60] was first recorded in 1532 by the physician and botanist Otto Brunfels (1488-1534) and later became widespread in European medical literature during the seventeenth century [142; 201:121-122]. However, the gallows mandrake tradition was strongest in German lands [195:60]. Talley [74:166-168] relates the legend that mandrakes come from the urine or semen of a thief hanged on the gallows to sacrificial rites and myths of pre-Christian Germanic people. He finds parallels between Odin's human sacrifice (in Nordic mythology) and the growth of the mandrake from urine or semen under the gallows, while Randolph [200:495] connects it to the myth of Prometheus (see below).

Starck [56:79] already concluded that the belief in the mandrake as a magical plant with human form which grew from the semen of a sleeping or dead man had its origins in Mesopotamia or Persia (see [41:115] for the same view), while according to van Arsdall et al. [142:330]: "Its origin is not known at the present

Page 8/42 
time." Our analysis of names supports the old idea that Iran is the cradle of the myths which relate mandrake to the creation of the first man as well as the origin of the plant from human semen and urine.

Another aspect of the mandrake-gallows connection is "the hand of glory." The dried hand of a hanged man was believed to have magical properties and was used by thieves and burglars [273:99-100]. The notorious hand of glory is known in French as the main de gloire, which is thought to be a corruption of the French for mandrake: mandragore. There is an obvious shared association with the gallows corpse [195:62]. The myth arose among thieves and illiterate persons during the Middle Ages in France through a misunderstanding of words, mandragore, the French term for the mandragora or mandrake, being mistaken for main de gloire. The term mandegloire is given as a popular synonym for mandragore [274:59].

All the names (14) related to gallows are from Europe, especially from Germany (7) and the Netherlands (4). Examples are: ["gallows' youngling"] and ["gallows' man"] in Dutch; ["torturer's root"], ["little gallows' man"], ["executioner's root"] and ["piss thief"] in German, which fortify the view that Europe is the cradle of this myth.

\section{Names related to religion and historical characteristics}

Adam's creation: Hildegard Von Bingen (twelfth c.) posits that the mandrake came forth from the same seed from which Adam was created, and to some extent its shape resembles that of man [259:1151A-1152A].

According to a Persian myth, man was created from a plant that resembled a human shape; this plant is a ribas (Rheum spp., rhubarb). The tradition says that Gayōmart, the first man, was created by Ahuramazda. When he died, there came a seed from his loins ... (it) was kept inside the soil. After forty years, it changed into ribas (or a mandrake) [267:12]). Eliade [275] has already pointed out the striking similarity between the myth of Gayōmart and the traditions about mandrake; the union of anthropomorphic plant and shining power which fertilizes the earth. Gayōmart's seed creates a hybrid creature, partway between a human being, an animal, and a plant [276:186]. Zarcone [41:120] concludes: "mandrake follows in the tradition of all the myths that mention the birth of humans from the earth at the beginning of time."

Despite these ancient Iranian myths concerning the creation of the first man and mandrake, which may have migrated very late to the West, there is no name in this language related to this issue. The Russian ["Adam's head"] and the Turkish ["Adam's plant"] may hint at a relic of the ancient Iranian myth. One might consider that the German legend has a negative connotation (spawn of evil), and all the eastern myths (as well as Hildegard von Bingen's text [259]) have a positive one (creation of peoples).

King Solomon: The name ["King Solomon tree"] in Arabic and in Armenian is a relic of an old legend that a piece of a mandrake was in the ring of King Solomon, who used it against demons. This story follows an old tradition handed down under the name of Hermes Trismegistos (first-third c.) via Ibn alBayțār [277, III:14] (13 ${ }^{\text {th }}$ c.). According to Amasiaci [198:96], in fifteenth-century Armenia, mandrake was called ["the tree of Solomon"]; it was thought to bring its owner happiness and power over people.

Circe: Dioscorides [45: 4.75] cites a specific plant called by the ancients "Circe's root" (kirkaía ríza/кıркаía piła) and, according to Pliny in Natural History [278: 25. 147], as Ciecaeon, referring to the passage in the Odyssey (10.210-43) in which Homer describes Circe, the mythical sorceress who turned men into sexually supercharged swine. Several authors have suggested that this enchanted plant was the mandrake [199:228-229; 200:501-505; 201:114; 279:204]. So, it is not surprising that this name persisted in English as ["herb of Circe"], Circée in French, and ["Circe's magical plant"] in German.

Prometheus: Apollonius of Rhodes (3rd century BCE [280: 3,843-868ff]) reports: "Prometheus was condemned to his punishment for theft...the flower sprang from his gore as it dripped to the ground." According to Randolph [200:495-496], "since gore does not drip from the bodies of hang-thieves, a change had to be made here...in adapting the story to the mandrake, and so the plant is said to spring from the thief's urine" (see also [29, II:338; 201:121; 281:passim]).

Van Arsdall et al. [142:293] reject this view. It still might be the origin of the thief/gallows/semen/urine myth. The question is, what happened with the story from the third c. BCE to the fifteenth c. AD? The semen and urine of a hanged thief in connection with the mandrake legend is relatively late, entering written sources only about 1,500 [195:59-60]; one name in German (["Prometheus plant"]) and the English name ["herb of Prometheus"] retain this old myth.

Paradise, mandrake, and the elephant. the mandrake's rare name ["elephant ear"] [202:249] is related to a medieval legend of the elephant and the mandrake. A Latin bestiary of the eighth or ninth century tells the tale of an elephant great in intellect but feeble in the desire to reproduce. The cure was for him and his mate to travel eastward until, near paradise, they found the mandrake plant [282:248]. A male and female elephant (Adam and Eve) require the fruit of the mandrake (here, the Tree of Knowledge) to arouse their sexual desire [283:153]. The German name ["little child's root"] indicates that this is the plant that the elephants ate in paradise [31:41].

\section{Non-classified names}

Some Greek names are included under this section: Euphemistic names. Euphemism has been in use since Greek antiquity as a kind of innocuous expression to describe or name something that is considered dangerous or unpleasant. By using bland, inoffensive terms, the speaker appears to treat the subject in a positive rather than pejorative way and avoids invoking its malign characteristics. In a way, euphemisms are used to politely refer to negative life issues such as disability, disaster, death. A very well-known euphemistic name is that of the Black Sea, which the Greeks called "Euxeinos Pontos" (= sea that welcomes foreigners) instead of the more suitable "Axenos" (unwelcoming to foreigners).

Non-classified names constitute the fifth widest category (27 names; Figure 2), indicating that a lot of names are of unknown origin despite all the abovementioned connections between names and the plant's properties, shape, or features. Languages such as Basque, Berber, Chinese, and Slovak all have names 
for the plant in this category, but ten more also have names in this group (Arabic, Catalan, Greek, Italian, Latin, Polish, Serbian, Spanish, Turkish, and Turkmenian).

Our hypothesis 1 suggests that due to the longer history and larger distribution area around the Mediterranean (especially in the Middle and Near East), it is expected to find migration of names (and myths and customs reflected in these names) from east to the west (Middle East to Europe) and from the south to the north (southern Europe to western and central and northern Europe) than migrations in the opposite directions.

Several authors [32:261; 41:115; 185:200; 191:89; 200:499; 227: 442, note 1] consider Persia to be the original home of mandrake superstitions based mainly on the role of the dog (see below), with a linguistic background (the origin of the word "mandragora"; see above) that was disputed by Asatrian [100:106].

Our data show that three Farsi mandrake names are related to the role of a dog in the pulling-out ceremony: sag-kuš (lit. ["dog slayer"], sag-šikan [lit. "dog breaker"], sag-kan [lit. "dog-dug"]). Two more names related to this issue occur in Arabic and Dagestani. The other mandrake names related to a dog (in five languages) are ["the dog apple"]. We asume that the mention of a dog in relation to the mandrake in western languages is a kind of echo of its role in the pulling-out ceremony in the Middle East (and Iran), since the use of a dog has deep roots in this region (see above).

As expected, we were unable to pinpoint any name's migration from northern Europe to the south or from Europe to the Middle East.

It was expected (hypothesis 2) that we would find more names (and in more categories) in countries in which the mandrake is native (especially around the Mediterranean) and has a longer history than in other parts of Europe in which mandrake (and its legends) arrived later. The order of the languages according to number of mandrake names (Table 8) (not counting spelling variants) is as follows: German 45 (including 3 Old German ones); Greek 35; Arabic 32; Turkish 31; Dutch 23; English 17; Serbian 15; Spanish 13; French 11, Latin 8, Polish 7, and Farsi 7. Since mandrake (M. officinarum/autumnalis) is a

Mediterranean/Middle-Eastern plant, our hypothesis must be rejected. Concerning the proliferation of the mandrake's German names, it seems that this reflects the importance of the mandrake in the local witchcraft and folklore in this country [252:12; 284:144].

Since mandrake has a long history as an aphrodisiac and as an omnipotent medicinal plant down the generations (see Benítez et al, 2021[13]), it was expected (hypothesis 3 ) to find relatively many names related to these categories (see hypothesis 3 ). In fact, we found (Table 3 ) relatively few names which express hallucinogenic or narcotic aspects ( 21 names) or are related to "love issues" (17 names), and even fewer related to its general medicinal properties (11 names). Thus, just $17 \%$ of total names are related to this category (Fig 2), and our third hypothesis must be rejected.

It was expected (hypothesis 4) that we would find more names related to witchcraft and black magic in Europe than in the Muslim world. Thompson [252:131] has already mentioned that "In Germany in medieval times belief in the powers of the mandrake became a universal cult, and through the country the plant was regarded with veneration for its magical properties." Names related to this category comprise $16 \%$ of the totals (Table 8, Fig. 2 ). Of the 49 names (Table 4), except for six in Arabic, six in Turkish, and one in Hebrew, the rest occur in European languages. Thus, this hypothesis was confirmed.

\section{Conclusions}

Mandrake has been named in diverse ways since antiquity, summing up to 296 vernacular names in 42 languages. The distribution of mandrake's vernacular names according to the designated categories reflects its widespread historical reputation as related to the Doctrine of Signatures, beliefs in its supernatural powers, mystic beliefs, and to a lesser extent its uses in magic and medicine.

Van Arsdall et al. [142] have already noted that different myths related to the mandrake have different origins and ages. Some are ancient while others are later, according to the written evidence. This observation could be examplified in several cases as inferred from spatiotemporal analysis of the mandrake names. The pulling-out ceremonies for the mandrake (especially with the use of a dog) originated in the Middle East. In this category we have 25 names, $28 \%$ of them from the Near East. The scream heard during the pulling out is a later phenomenon [142:317] and is reflected in four European languages and in Turkish.

The relation of the mandrake's names to magic and witchcraft appears only in European countries in which the mandrake is non-native (Table 4, D1). This is also indirect evidence for a later expansion of these beliefs after the introduction (or import of the roots) of the mandrake to these countries. Names which are related to demonic agents (as a result of the similarity to the human shape) appear mainly in Arabic but also in 7 European languages, most of them from countries in which the mandrake is not indigenous. This finding may provide indirect support for Middle-Eastern origin of this aspect. Thus it seems that witchcraft and magical traditions originated mainly in central Europe (see above), while the fear of the plant due to its shape may have an eastern origin.

The origin of the mandrake under the gallows has late, western roots. All the names related to gallows are from Europe (14), especially from Germany (7) and the Netherlands (4) and for sure reflect a late-medieval European origin.

\section{Declarations}

Acknowledgements: We are thankful to: Ela Harrison (German), Shula Vardi (French), Yonathan Bar-On (Dutch and German), Dr. Sonia Klinger (Polish), Hava Lahav (Czech), Sorin Solomon (Romanian), Prof. Michael Lukas Petersen (Danish), Dr Gitte Peterson (Danish), Prof. George Fayvush (Armenian), Dr. Margareta Walczak (Polish), Prof. Petr Pyšek (Czech), Prof. Zoltán Barina (Hungarian), and Dainius Razauskas (Estonian) for checking the validity and accuracy of the mandrake's names and for text translations.

Authors' contributions: AD and GB designed and conceived the study. All of the authors collected names in their own languages, checked their validity and meaning, and participated in the data analysis and discussion. AD and GB prepared, revised, and finalized the manuscript. All authors read and approved the 
final manuscript.

Funding. This work was financially supported by the Henk and Dorothy Schussheim Fund for Ecological Studies in Mt. Carmel.

Availability of data and materials. Not applicable.

Competing interest. The authors declare no competing interests.

Ethics approval and consent to participate. Not applicable.

Consent for publication. Not applicable.

Author details: 1. Department of Evolutionary and Environmental Biology and Institute of Evolution, University of Haifa, Haifa, Israel. amots.dafni@gmail.com, adafni@research.haifa.ac.il

2. GREB-BioC, Botany Laboratory, Faculty of Pharmacy and Food Sciences, University of Barcelona. Av. Joan XXIII s/n, 08028, Barcelona, Catalonia (Spain). cesarblanche@ub.edu

3. Mghar 20128. Israel. salehaqil58@gmail.com

4 Laboratory of Biogeography and Ecology, Department of Geography, University of the Aegean, 81100 Mytilene, Greece. t.petanidou@aegean.gr

5 Department of Arabic Language and Literature, Faculty of Languages, History and Geography, Ankara University, Ankara,

Turkey.bedrettin.aytac@gmail.com,baytac@ankara.edu.tr

6 Department of Life Sciences, Università degli Studi di Siena, Siena, Italy. ettore.pacini@unisi.it

7 Medical University of Sofia, Faculty of Pharmacy, Department of Pharmacognosy, Dunav 2 sr. Sofia 1000, Bulgaria. Ina_Kozuharova@yahoo.co.il

8 Department of Arabic Language and Literature, University of Haifa, Israel. agkleinberger@gmail.com

9 Department of Middle Eastern and Islamic Studies, the Ezri center for Iran and Persian Gulf Studies, the University of Haifa, Israel, sshahvar@univ.haifa.ac.il

10 University of Belgrade, Faculty of Agriculture, Department of Applied Botany, Nemanjina 6, 11080 Belgrade, R. of Serbia, DAJIC@agrif.bg.ac.rs

11 Centre for Information Modelling, University of Graz, Austria, helmut.klug@uni-graz.at

12 Department of Botany, University of Granada, Campus Universitario de Cartuja, 18071 Granada, Spain, gbcruz@ugr.es

\section{References}

1. Gledhill D. The Names of Plants. Cambridge: Cambridge University Press; 1989.

2. Petanidou T. Terraces of the Aegean - the example of the Dodecanese. Athens: Parisianou Scientific Publications; 2015.

3. Petanidou T. Terminology on terraces. Nissos Andros 2018;12:168-178. (In Greek).

4. Vallès J 1996. Los nombres populares de las plantas: método y objetivo en etnobotánica. Hernández EB. (ed.). Monografías del Real Jardín Botánico de Córdoba 3:7-14.

5. Flattery DS, Swartz M. Haoma and Harmaline: The Botanical Identity of the Indo-Iranian Sacred Hallucinogen "Soma" and its Legacy in Religion, Language and Middle Eastern Folklore. Berkeley: The University of California Press; 1989.

6. Šeškauskaite D, Gliwa B. Some Lithuanian ethnobotanical taxa: a linguistic view on Thorn Apple and related plants. J. Ethnobiol. Ethnomed. 2006; 2: 13 https://doi.org/10.1186/1746-4269-2-13

7. Austin DF, Felger RS. Sichuan peppers and the etymology of Fagara (Rutaceae). Econ. Bot. 2008; 62(4):567-573.

8. Austin DF. Sambucus intercultural exchange and evolution. Ethnobot. Res. Appl. 10: 213-234. 2012.

9. Dafni A, Benítez GC, Blanché C, Rammón-Laca L, Petanidou T, Aytaç B, Horvat M, Lucchese F, Geva-Kleinbergeri A. The etymological, ecological, historical and ethnobotanical roots of the vernacular names of Ecballium elaterium (L.) Rich. (Squirting cucumber). J. Ethnobiol. Tradit. Med. Photon, 2013;119:515-537.

10. Silberman HC. Superstition and medical knowledge in an Italian hHerbal. Pharm. Hist., 1996;38(2):87-94.

11. Carter AJ. Myths and mandrakes. J. Roy. Soc. Med. 2003;96:144-147.

12. Waniakowa J. Mandragora and belladonna - the names of two magic plants. Studia Linguistica Univ. lagellonicae Cracoviensis 2007:124:161-73.

13. Benítez G, Böck B, Vulfsons S, Leonti M, Dafni A. The rise and fall of the mandrake as a medicinal plant. J. Ethnopharmacol. 2021. (In press). 
14. Kors A, Peters A.C. (eds). Witchcraft in Europe, 400-1700: A documentary History. Philadelphia: University of Pennsylvania Press; 2001.

15. Maxwell-Stuart PG. Witchcraft in Europe. London: Macmillan International Higher Education; 2001.

16. Harner MJ. The Role of Hallucinogenic Plants in European Witchcraft. In: Hallucinogens and Shamanism. Harner MJ. (ed.). Oxford: United Kingdom: Oxford University Press; 1973,125-150.

17. Sultana, A., 2011. Belief and practice of "Black magic"and its implications for Pakistani muslim society. In: Supporting Cultural Differences Through Research. 2011 Monograph Series 19th Annual Conference. February 14-19. Louisiana: Baton Rouge; 1349-2364.

18. Kamali MH. Islam's Views on Sorcery and Black Magic. ICR Journal, 2011; 2(3). https://scholar.google.co.il/scholar? $\mathrm{hl}=$ en\&as_sdt=0\%2C5\&q=+black+magic + witchcraft+islam\&btnG=

19. Perlmutter D. The politics of Muslim magic. MEQ. Spring 2013: 73-80.

20. Ungricht S, Knapp S, Press JR. A revision of the genus Mandragora (Solanaceae). Bull. Nat. Hist. Mus. Bot. Ser. 1998;28: 17-40.

21. Hawkes JG. Mandragora. In: Flora Europaea. Tutin TG, Hywood VH, Burges NA, Moore DM, Valentine DH, Walters SM, Webb DA. (eds.), Cambridge: Cambridge University Press. 1972;3:193-201.

22.Volis S, Fogel K, Tu T, Sun H, Zaretsky, M. Evolutionary history and biogeography of Mandragora L. (Solanaceae). Mol. Phylogenet. Evol. 2018;129: 85-95.

23. Volis S, Tu T, Deng T, Zaretsky M, Fogel K, Sun H. Phylogeographic study of Mandragora L. reveals a case of ancient human assisted migration. Isr. J. Bot. PI. 2015;18;62(3):176-86.

24. González Hernando I. El fruto del deseo: connotaciones sexuales de la mandrágora desde Egipto hasta la Edad Media. Revista Digital de Iconografía Medieval 2017;9 (17):61-79.

25. Gallego MJ. Mandragora L. In: Flora Iberica Vol. 11. Castroviejo S. et al., (eds.). Madrid: Consejo Superior de Investigaciones Científicas, 2012,211-214. (In Spanish).

26. Duke JA. Handbook of Medicinal Herbs. Boca Raton, Fla.: CRC press; 2002.

27. Rätsch C. The Encyclopedia of Psychoactive Plants: Ethnopharmacology and its Applications. New York: Simon and Schuster; 2005.

28. Stephenson J. Hahnemannian Provings. New Delhi: B. Jain Publishers; 1998.

29. De Cleene M, Lejeune MC. Compendium of Symbolic and Ritual Plants in Europe, vol. 2 (Herbs). Ghent: Mens \& Cultuur Uitgevers; 2003.

30. Hambel, V., Die alte Heydnische Abgöttische Fabel von der Alraun: Verwendung und Bedeutung der Alraune in Geschichte und Gegenwart. Universität Passau. Diplomarbeit im Studiengang Sprachen-, Wirtschafts- und Kulturraumstudien. 2002. http://docplayer.org/69590247-Die-alte-heydnische-abgoettischefabel-von-der-alraun.html

31.Wittlin D. Mandragora eine Arzneipflanze in Antike, Mittelalter und Neuzeit. Basler Dissertationen zur Geschichte der Pharmazie und Naturwissenschaften. Band 14. Basel: Dietikon: Juris Druck und Verlag; 1999.

32. Starr F. Notes upon the mandrake. Am. Antiq. Orien. J. 1901;23:258-268.

33. Cule J. The Devil's Apples. Vesalius 1997;3: 95 -105.

34. Chaurasia OP, Ballabh B, Tayade A, Kumar R, Kumar GP, Singh SB. Podophyllum L.: An endangered and anticancerous medicinal plant-An overview. Ind. J. Trad. Know. 2012;11: 234-241.

35. Corns CM. Herbal remedies and clinical biochemistry. Ann. Clin. Biochem. 2003;40: 489-507.

36. Gorun G, Curcă GC, Hostiuc S. Buda O, Legal highs” in Romania: historical and present facts. Rom. J. Leg. Med. 2011;19:73-76. DOI: 10.4323/rjlm.2011.73

37. Mitrović A. Mein Besuch bei einer Zauberfrau in Norddalmatien“. Anthropophyteia, 1907; 4:.227-236.

38. Reč K. 2014. Rečnik svetih i magijskih biljaka. (Dictionary of saint and magic plants). Belgrade: Babun; 2014. (In Serbian).

39. Rudkin EH. Lincolnshire folklore. Folklore, 1933;44(2):189-214.

40. Eliade M. Zalmoxis, the Vanishing God. Chicago and London: University of Chicago Press; 1972.

41. Zarcone T. The myth of the mandrake, the 'plant-human'. Diogenes 2005; 52:115-29.

42. Schmidbauer W. Die magische Mandragora. Antaios 1969;10: 271-283. (In German).

43. Lowinsky NR. What the Centaur Said: Of Sacred Springs, Neolithic Caves, and the Mysteries of Thrace. Psycholo. Perspec. 2003;45: 90-115.

Page 12/42 
44. Taussig, M. 2003. The Language of Flowers. Criti. Inquiry 30: 98-131.

45. Dioscorides. Materia Medica. In Thesaurus Linguae Graeca - A digital Library of Greek Literature. University of California,

Irvine. http://stephanus.tlg.uci.edu. Accessed 23 Feb 2019.

46. Alcover, $A$, and E. Moll (eds.) Diccionari català-valencià-balear: inventari lexicogràfic i etimològic de la llengua catalana en totes les seves formes literàries i dialectals. vol. 7. (LI-OM). Palma de Mallorca: Mn Alcover;1956. (In Catalan).

47. Bilz M, Kell SP, Maxted N, Lansdown RV. European Red List of Vascular Plants. Luxembourg: Publications Office of the European Union; 2011.

48. Avanesyan, G.A. Armenian medicine of the Middle Ages. Bull. Med. Int. Conf. Saratov: Russia Limited Liability Company Science and Innovation. 2013;3(11):1268-1269.

49. Simeon E. Bogomily and bogomils. Cereal Grain, 2000;3-4: 9-12. (In Bulgarian).

50. Sedir P. Botanical dictionary to the magical plants. 2017 http://friendsoftherainbow.net/node/1770

51. Georgieva A. Light on magic and sacral medicine. Éva Póch (Ed.). The Magical and Sacred Medical World. Newcastle upon Tyne, Tyne: Cambridge Scholars Publishing, 2019, 541 pp.

52. Falucci FD. 1972. Vocabolario dei dialetti della Corsica. Firenze: Licosa Reprints; 1972. (In Italian).

53. Van Lis W. Gualtheri van Lis Pharmacopoea. Amsterdam: Jan Morterre; 1764). (In Dutch).

54. Britten J. A Dictionary of English Plant Names. Part I. London: Trübner and Co,: 1886.

54. Turner W. The first and seconds partes of the herbal of William Turner. Collen. London: Arnold Birckman; 1568.

56. Starck AT. Der Alraun. Ein Beitrag zur Pflanzensagenkunde. Ottendorfer Memorial Series of Germanic Monographs 14. Baltimore: J.H. Furst Company; 1917.

57. Politis NG. Laografika symmeikta, vol. III. Athens: Akadimia Athinon - Dimosievmata Laografikou Archeiou No 6; 1931. (In Greek).

58. Kavvadas DS. Eikonografimenon BotanikonPhytologikon Lexicon. (Illustrated Botanical Dictionary) volumes 1-9, Athens: Pigassos; 1956. (In Greek).

59. Kritikos PG. O mandragoras. Laografia - Deltion thw Ellinikis Laografikis Etaireias, vol. 19: 399-452 , Athens:1960-1961. (In Greek).ce).

60. Vlastos P. Synonyma kai syggenika - Nea ekdosi sympliromeni apo ta kataloipa tou syggrafea. Athens: Etaireia Ellinikou Logotechnikou \& Istorikou Archeiou (ELIA); 1989. (In Greek).

61. Theophrastus E. Enquiry into Plants. Hort A. (transl.). London: William Heinemann; 1916.

62. Papakonstantinou Th. Mandragora. In: Megali Elliniki Egkyklopaedia, vol. 16. Athens: Foenix Publishing Organization; 1956. (In Greek).

63. Nemnich PA. Neues Waaren-Lexicon in zwölf Sprachen, Deutsch, Hollandisch, Danisch, Schwedisch, Englisch, Französisch, Italienisch, Spanisch, Portugiesisch, Russisch, Neugriechisch und Lateinisch. Band I Hamburg: Nemnichschn Buchhaldung; 1820. (In German).

64. Géczi J. Egy szempont a biológia-tankönyvek szövegének és illusztrálásának vizsgálatához. Iskolakultúra, 1999:9(5);55-69. (In Hungarian).

65. Penzig O. Flora Popolare Italiana. Bologna Orto Botanico, Genoa, Reprint Edizioni Edagricole; 1924. (In Italian).

66. Anthos 2019. Sistema de información sobre las plantas de España. http://www.anthos.es/ .accessed 12 March 2019.

67. Tumanova ОT. "Rasteniia v tekstakh Biblii" [Plants in the texts of the Bible]. Russkaia rec', 2001;2:75-78.[in Russian].

68. Ushakov D. The Great Interpretive Dictionary of the Russian Language. Moscow: The modern edition of the Slavic Book House; 2014.

69. Nurmukhamedova, RA, Karomatov ID, Baymuradov RR. Mandrake and medicine. Biol. Integ. Med. 2017;4:17-195.

70. Simonović D. Botanički rečnik, Srpska Akademija Nauka i Umetnosti, Posebna izdanja, knjiga 3, Naučno delo, Beograd, p. 291 (Botanical Dictionary). Belgrad: Serbian Academy of Sciences and Arts, Special issue, Book 3, Naučno delo; 1959. (In Serbian).

71. Stojanović D, Jančić I, Jančić R. Dar neba ili cveće zla - psihoaktivne i druge opasne biljke Balkanskog poluostrva, Autorsko izdanje, Beograd, (Gift of heaven or evil flowers - psychoactive and other dangerous plants of Balkan peninsula). Belgrade: Author's publishing; 2017. (In Serbian).

72. Mizgireva OF. Turkemenian mandrake. Probl. Bot. 1955; 2:167-205.

73. Hauenschild I. Türksprachige Volksnamen für Krauter und Stauden mit deutschen, englisschen und Russischen Bezeichnungen. Wiesbaden: Otto Harrassowitz; 1989.

Page $13 / 42$ 
74. Talley, E. Runes, Mandrakes, and Gallows. In: Myth in Indo-European Antiquity Gerald James Larson, Scott Littleton C, Puhvel J. (eds.). Berkeley: University of California Press; 1974:157-168.

75. Pritzel GA, Jessen KFW. Die deutschen Volksnamen der Pflanzen: neuer Beitrag zum deutschen Sprachschatze. Berlin: Philip Cohen; 1882 (In German).

76. Grellman HMG. Geschiedkundige verhandeling over de heidens, betreffende hunne herkomst, leevenswijze, gesteldheid, zeden en lotgevallen, sedert hunne verschijning in Europa, vol. 1. Dordrecht: bij A. Blussé \& Zoon; 1791.

77. Hocking GM. Radix Mandragorae. Q. J. Crude Drug Res. 1963;3: 332-335.

78. Hallfast, E. "Onko tuo ankka jonka näen edessäni?": Terry Pratchettin Wyrd Sisters-teoksen parodisten Shakespeare-viittausten suomentaminen teoksessa Noitasiskokset (Master's thesis). 2019. https://trepo.tuni.fi/bitstream/handle/10024/115998/HallfastEmily.pdf?sequence=2

79. Thomasius J. Disputatio Philologica, De Mandragora: In Academia Lipsiensi D. XIX. Calend. lanuar. A. MDCLV. Litteris Hendelianis. 1739 (In Latin).

80. Rätsch C, Müller-Ebeling C. The Encyclopedia of Aphrodisiacs: Psychoactive Substances for Use in Sexual Practices. New York: Simon and Schuster; 2013.

81. Fetzner A. Die alraune Pflanze-Pflanze der Liebe, Pflanze des Tods. BoD Books on Demand. Norderstedt. Münster:Druck der Theiddingschen Buchhaldung; 2019.

82. Schweizerischev Idiotikon https://digital.idiotikon.ch/idtkn/id1.htm\#!page/10173/mode/1up. Accessed 24 Dec 2019.

83. Langstedt FL. Allgemeines botanisches Repertorium. Band 1:A-F. Nürnberg: Raspeschen; 1801.(In German).

84. Barney SA, Lewis WJ, Beach JA, Berghof O. The Etymologies of Isidore of Seville. Cambridge: Cambridge University Press; 2006.

85. Al-Isbili, Abu I-Hayr. Kitabu 'Umdati Ttabib Fi Ma'rifati Nnabat Likulli Labib (Libro base del médico para el conocimiento de la Botánica por todo experto). vol. II (Fuentes Arábico-Hispanas) de Abu I-hayr al-Isbili; Córdoba FC, Tilmatine C, Costa JB.

86. Levey M. Early Arabic Pharmacology: An Introduction Based on Ancient and Medieval Sources. Leiden: Brill; 1973.

87. Said HM, Hamarneh SK. Al-Biruni Book on Pharmacy and materia Medica. Karachi: Hamdard National Foundation; 1973.

88. Sontheimer von J. Aus dem Arabischen uebersetzt. Hallberger'sche Verlagshandlung, Stuttgart. Grosse Zusammenstellung über die Kräfte der bekannten einfachen Heil-und Nahrungsmittel, von abu Mohammed Abdallah ben Ahmed aus Malaga bekant under der namen Eben Baithar. (Tansl.) vol. 2. Stuttgart: Hallberger'sche Verlagshandlung;1842.

89. Aburjai T, Hudaib M, Tayyem R, Yousef M, Qishawi M. Ethnopharmacological survey of medicinal herbs in Jordan, the Ajloun Heights region. J. Ethnopharmacol. 2007;110: 294-304.

90. Abu-Rabia A. Indigenous medicine among the Bedouin in the Middle East. New York: Berghahn Books; 2015.

91. Smith G. The Evolution of the Dragon. Manchester and London: Elliot; 1919.

92. Bnouham M, Merhfour FZ, Elachoui M, Legssyer A, Mekhfi H, Lamnaouer D, Ziyyat, A, Toxic effects of some medicinal plants used in Moroccan traditional medicine. Moroccan Journal of Biology 2006;2:21-30.

93. Aberbach M, Grossfeld B. Targum Onkelos to Genesis: A Critical Analysis together with an English Translation of the Text. New York: Ktav Publ. House. 1982.

94. Steinsaltz A. Talmud Bavli (Hebrew translation). Jerusalem; Hamachon Halsraeli Lepirsumim Talmudiim; 1967-2010.

95. Steingass FJ. A Comprehensive Persian-English Dictionary: Including the Arabic Words and Phrases to be Met with in Persian Literature, Being, Johnson and Richardson's Persian, Arabic, and English Dictionary, Revised, Enlarged, and Entirely Reconstructed. New Delhi: Asian Educational Services; 1992.

96. Ibn Sina I. Kitāb al-Qānūn fĩ al-Tibb. (Canon of Medicine). Book 2: Materia medica. New Delhi: Jamia Hamdard; 1998. (In Arabic).

97. Devellioğlu F. Osmanlıca-Türkçe Ansiklopedik Lûgat. Ankara: Doğuş Ltd.Şti. Matbaası;; 1962. (In Turkish).

98. Houtsma, M. T. Walker A., R. Basset, and R. Hartmann, (eds). The Encyclopaedia of Islam: A Dictionary of the Geography, Ethnography, and Biography of the Muhammedan Peoples. vol 4. Leiden: EJ Brill Limited; 1934.

99. Dehkhoda, 'Ali Akbar. Loghatnameh-ye Dehkhoda. Tehran: Mu'assasah-ye Entesharat va- Chap-i Daneshgah-e/ Tehrn,

2003. http://www.vajehyab.com/dehkhoda/\%D8\%A7\%D8\%A8\%D8\%B1\%D9\%88\%D8\%B5\%D9\%86\%D9\%85/ Accessed 18 May 2020.

100. Asatrian G. Marginal remarks on the history of some Persian words. Iran and the Caucasus, 2012;16(1):105-116.

101. Arakelova, VThe Onion and the Mandrake: Plants in Yezidi Folk Beliefs. J. Persian. Stu. 2014; 7:149-156.

Page $14 / 42$ 
102. Khapizov S. The Mandrake in East Caucasian Folk Beliefs. Iran and the Caucasus, 2019;23(3):.248-255.

103. Šumavský J, Rank, J. Taschenwörterbuch der böhmischen und deutschen Sprache. Böhmischdeutscher. Prag: Theil; 1859.

104. Zíbrt Č. Mandragory. Rudolfa II. Český 1903; 12:288-297. (In Czech).

105. De Cleene M. Giftige bloemen on planten. Antwerpen: Garanat Uitmbling; 2016. (In Dutch).

106. Timmer M. Van anima tot Zeus: Encyclopedie van begrippen uit mythologie, religie, alchemie, cultuurgeschiedenis en analytische psychologie. Rotterdam: Lemniscaat; 2001. (In German).

107. Beets N. Nieuwe verscheidenheden: meest op letterkundig gebied. Bohn: De Erven;1890. (In German).

108. Huygens C. Koren-Bloemen: Nederlandsche Gedichten. vol 2. Amsterdam: Van Ravesteyn; 1672. (In Dutch).

109. Andrews S. Herbs of the Northern Shaman. Blue Ridge Summit: John Hunt Publishing; 2010.

110. Parkinson J. Paradise in Sole, paradisus terrestris. London: Metheun and Co.; 1629 (1904).

111. Matin P. Mandrake a plant totem. 2013 https://yerevan.academia.edu/pmatin

112. Cotgrave R. A French-English Dictionary. London: Luke Faune; 1650.

113. Daunay MC, Laterrot H, Janick J. Iconography and history of Solanaceae: antiquity to the 17th century. Hort. Rev. 2007;34:1-111.

114. Friedrich T. Hexenkräuter wissenschaft und mythos. Diplomarbeit zur Erlangung des akademischen Grades Magistra der Naturwissenschaften an der Fakultät für Naturwissenschaften und Mathematik der Universität Wien ausgeführt am Institut für Pharmakognosie Vorstand. Wien. 2002) (In German). https://www.scribd.com/doc/215353942/Hexenkrauter-Wissenschaft-und-Mythos-126-S-pdf

115. De Genlis SF. Die Botanik der Geschichte und Literatur oder die Pflanzen in ihren mythologischen, religiösen, bürgerlichen, sinnbildlichen, abergläubischen, sprüchwörtlichen, literarischen, ästhetischen, und geschichtlichen Beziehungen, Band 2.Bamberg and Würzburg: Goebhardt; 1813. (In German).

116. Siegel RK, West LJ. Hallucinations: Behavior and Theory. New Jersey: John Wiley \& Sons; 1997.

117. Schultes, R.E. and Hofmann, A., The Botany and Chemistry of Hallucinogens. (1973). Springfield, III: Charles C. Thomas, Publisher; 1973.

118. Anthon EF. Manuel de synonymie chimico-pharmaceutique on nomenclature de toutes les dénominations latines, allemandes et françaises des produits chimiques et matières premières médicinales. Paris: J. Rothschild; 1862. (In French).

119. Ulrich W. Internationales Wörterbuch der Pflanzennamen: in Lateinischer, Deutscher, Englischer und Französischer Sprache: zum Gebrauche für Botaniker, Lehrer, Pharmaceuten, Mediciner, Droguisten Handelsgärtner, Landwirthe und Forstmänner. Leipzig: H. Schmidt \& C. Günther; 1872 . (in German).

120. Madaus G. Lehrbuch der biologischen Heilmittel. Band 8. (Reprint of the Leipzig edition by Georg Thieme from 1938). Ravensburg: Mediamed Verlag; 1987. (In German).

121. Anastassiades J. Mandragora officinarum; its toxicity. Cyprus Med. J. 3: 357-360;1950.

122. Clark HF. The Mandrake Fiend. Folklore, 1962;73:257-269.

123. Baytop T. Türkçe Bitki Adları Sözlüğü. (3th edition). Ankara: Atatürk Kültür, Dil ve Tarih Yüksek Kurumu, Türk Dil Kurumu; 2007. (In Turkish).

124. Tarhan N, Arslan M, Sevgi ŞA. Bazı tıbbi bitkiler ve onlara ait mitoslar. Mersin Üniversitesi Tıp Fakültesi Lokman Hekim Tıp Tarihi ve Folklorik Tıp Dergisi. 2016;6(1):1-9.

125. छlšbīliyy, Abū al-Khayr. Kitāb đUmdat al-Ṭabīb fī Mađrifat al-Nabāt [The Pillar of the Doctor on the Knowledge of the Plants]. Bayrūt: Dār al-Garb alIslāmiyy; 1995. (In Arabic).

126. Ciancaglini CA. Iranian loanwords in Syriac: Beiträge zur Iranistik.Wiesbaden: Reichert; 2008.

127. Avicenna. Canon of Medicine. Book II: Materia Medica. New Delhi: Department of Islamic Studies, Hamdard University. 1998

128. Kahl J. Sābūr ibn Sahl's Dispensatory in the Recension of the 『Adudī Hospital. Leiden: Brill; 2008.

129. Boulos L, Gohary M. Medicinal Plants of North Africa. Algonac, Michigan: Reference Publications, Inc.;1983.

130. Harvey JH. The book of Abūl-Khayr. Gard. Hist. 1993;21: 118-120.

131. Medina-Gavilán JL. Flora de Burguillos (Sevilla): bases para su conservación. Diputación de Sevilla-Ayuntamiento de Burguillos. Sevilla; 2011. (In Spanish). 
132. Bak A. đĪsā, Mu囚ğam \Asmā⿴ il-Nabātāt [=The Lexicon of the Names of the Plants]. Al-Qāhira: al-Maṭba'a al-Amīriyya; 1930 (In Arabic).

133. Howell J. Lexicon Tetraglotton, an English-French-Italian-Spanish Dictionary. London: Samuael Thompson; 1990. (1660).

134. Marzell, H. and Wissmann, W., 1937. Worterbuch der deutschen Pflanzennamen. Band III. Leipzig: Hirzel; 1937. (In German).

135. Regel C. Das mittelniederdeutsche Gothaer Arzneibuch und seine Pflanzennamen. Ernestin zu Gotha: Osterprogr. des Gymnas; 1873. (In German).

136. Lexer M. MittelhochdeutSche WörterBücher. Leipzig: Hirzel; 1872. (In German).

137. Diefenbach L. Wülcker E. Hoch-und nieder-deutsches Wörterbuch der mittleren und neueren Zeit. Basel: B. Schwabe; 1885. (in German).

138. Leclerc LM. Le traité des simples d'Ibn al- Baytar. vol 3.Paris: Institut du monde arabe; 1881.(In French).

139. Altbauer, M., Studies in the Vocabulary of the Byelorussian Translations of the Bible. J. Belarus. Stud.. 1972;2(4):359-368.

140. Johnson F. A dictionary, Persian, Arabic, and English by Francis Johnson. London:Wm H. Allen and Company; 1852.

141. Russell JR. Zoroastrianism in Armenia. Harvard: Harvard University, Department of Near Eastern Languages and Civilizations and National Association for Armenian Studies and Research; 1987

142.Van Arsdall A, Klug HW, Blanz P. The mandrake plant and its legend: a new perspective, In: Old Names - New Growth. Bierbaumer P, Klug HW. (eds.). Proceedings of the 2nd ASPNS Conference, University of Graz, Austria, 6-10 June 2007, Peter Lang. 2009:285-346.

143. Tatarakis A.M.. Ae di' epodon therapeiae. In: Neoellinika Analekta, Vol. A, p. 337. Filologikos Syllogos Parnassos - Vivliopoleion Noti Karavia, Athinae. 1872.

144. Budge EAW. (ed.). Syrian Anatomy, Pathology and Therapeutics: Or the Book of Medicines. (vol. 2). Oxford: Oxford University Press; 1913.

145. Weitland P. Kunstwoordenboek. Gravenhage:Wediwe J. Allart; 1824. (In German).

146. Van der Velde J. Volledig Nederduisch-Fransch woordenboek. Bruxelles: Greeuse; 1848 (In Dutch).

147. Conway DJ. Norse Magic. Woodbury, MN: Llewellyn Worldwide; 1991.

148. Janssens J. De alruin in het volksgeloof. Van Mensen en Dingen. 2017; 15:2-6. (In German)

149. Blom JD. A Dictionary of Hallucinations. New York, NY: Springer; 2010

150. O'Reilly, E. (). Sans Gaoidhilge-Sagsbhearla. An Irish-English Dictionary. Dublin: Barlow;

1817. https://pharmacy.erciyes.edu.tr/ckfinder/userfiles/files/Bitirme\%20Projeleri/2019/Bu\%C4\%9Fra\%20ZORO\%C4\%9ELU\%20Tez.pdf accessed 20 Jan 2020.

151. Riedel J. C. , Kurzabgefastes Garten-Lexicon: in welchem nicht allein die in und ausländischen Blumen, Gewächse, Stauden, Bäume und Kräuter, nach ihrer Gestalt, Natur, Erziehung, Vermehrung, Wartung und Erhaltung, gründlich beschrieben werden; sondern auch von andern zur Gärtnerei dienlichen Wissenschaften und Verriuchtungen hinlänglicher Unterricht zu finden ; mit einem nüzlichen Garten Kalender. , Nordhausen: J.H. Groß; 1751. (In German).

152. Bugát P. Természettudományi szóhalmaz. Budán: Magyar Királyi Egyetem; 1843.(In Hungarian).

153. Olesen A. Hekseurter og folketro. København: Hovedland; 2019. (In Danish).

154. Baber, Zehir el Din. Memoirs of Zehir-Ed-Din Muhammed Baber: Emperor of Hindustan. Leyden J, Erskine W. (transl.); Waddington C. (ed.) London: Longman, Rees, Orme, Brown, and Green, 1826.

155. Särkkä H. Englantilais-suomalais-englantilainen yleiskielen käyttösanakirja. Helsinki: Otava; 1992. (In Finnish).

156. Lauchert F. Geschichte des Physiologus. Strasburg. Trübner; 1889. (In German).

157. Beveridge AS. The Babar-Nama Description of Farghana. J. R. Asiat. Soc. 1910;42:111-128.

158. Delathauwer LA. Het Belgischkruitboek. Gent: H. Hoste; 1848. (In Dutch).

159. Von Mosig A. Radix Mandragorae. Int. J. Crude Drug Res. 1963; 3(1):332-335.

160. Duchesne EA. Repertoire des plantes utiles et des plantes vénéneuses du globe. Paris: J. Renouard; 1836. (In French).

161. Vahot I. Matyas Diak Naptara. Bodapesti: Müller; 1857. (In Hungarian).

162. Loudon JC. An Encyclopaedia of Gardening. London: Longman, Rees, Orme, Brown, Green, and Longman; 1829. 
163. Bouquet J. La Mandragore en Afrique du Nord. Bull. Soc. Sc. Na.t Tunisie, 1952;5:29-44. (In French).

164. Crowfoot GMH, Baldensperger L. From Cedar to Hyssop. London: The Sheldon Press; 1932.

165. Post GE. Flora of Syria, Palestine and Sinai. vol 2. Beirut: American Press; 1933.

166. Venzlaff H. Der marokkanische Drogenhändler und seine Ware: e. Beitr. zu Terminologie u. volkstüml. Gebrauch traditioneller arab. materia medica (vol. 31). Franz Steiner Verlag: Wiesbaden; 1977. (In German).

167. Noun, J. Neglected and underutilized plant species in the shouf-aley area of lebanon: An ethnobotanical study. In Region. Workshop Biodiver. Food. 2006. http://www.underutilized-species.org/Documents/PUBLICATIONS/moa_aub_feb_06.pdf. Accessed 8 Jan 2020.

168. Dalman G. Arbeit und Sitte in Palästina. Band I: Von der Ernte zum Mehl. Bertelsmann:Nachdruckaufl. der Ausgabe Gütersloh; 1928.

169. Wahrmund A. Handwörterbuch der neu-arabischen und deutschen Sprache (vol. 2). J. Ricker.Wiesbaden: Otto Harrassowitz; 1870. (In German).

170. Thomson WM. The Land and the Book, or Biblical Illustrations Drawn from the Manners and Customs, the Scenes and Scenery of the Holy Land. London: T. Nelson and Sons; 1872.

171. Harrison RK. The Mandrake and the Ancient World. The Evangel. Quart. 1956;28: 87-92.

172. Dickie J. The Hispano-Arab garden its philosophy and function. Bull. Sch. Orient. Afr. Stud. 1968;31(2):237-248.

173. Jaradat NA, Al-Ramahi R, Zaid AN, Ayesh OI, Eid AM. Ethnopharmacological survey of herbal remedies used for treatment of various types of cancer and their methods of preparations in the West Bank-Palestine. BMC Complement. Altern. Med. 2016;16(1): p.93. DOI: 10.1186/s12906-016-1070-8

174.Kitto OJ. A Cyclopaedia of Biblical Literature. New York: Newman; 1846.

175. Rossiter W. An illustrated dictionary of scientific terms. London and Glasgow: William Collins, Sons, and Company; 1870.

176. Holzman RS. The legacy of Atropos, the fate who cut the thread of life. Anesthesiology. 1998;89:241-249.

177. Vaios Ntavos. Ten myths about goblins from all over Greece. LIFO 28.12.2019.

178. Mátyás B. Balogh Mátyás: A mongóliai burját sámánok viselete és eszközei. 2016. https://seven-cornered21.rssing.com/chan-11700108/latest.php. Accessed 12 Feb 2020.

179. Riddle J M. Goddesses, Elixirs, and Witches. New York: Palgrave Macmillan; 2010.

180. Friend H. Flowers and Flower Lore. vol 2. London: W Swan Sonnenschein; 1884.

181. Taylor, B., 1900. Storyology: Essays in Folk-lore, Sea-lore, and Plant-lore. London; E. Stock; 1900.

182. Nathanius J. Die Blumenwelt ihre deutchen Namen Sinn und Deutung. Band 12. Leipzig: Arnoldifache, Oage \& Glucksmanncen; 1868.

183.Ostling M. Witches' Herbs on Trial. Folklore, 2014;125:179-201.

184. Runovskij A. "Dnevnik polkovnika Runovskogo, sostoyavšego pristavom pri Šamile vo vremya prebyvaniya ego v gorode Kaluge, s 1859 po 1862 god” (1904), Akty Kavkazskoy arxeografičeskoy komissii XII, Tiflis: 1904: 1468-1506 (cited by [201:250].

185. Vöth PJ. De Alruin en de Heggerank. Arch. Int. Ethnog. 1894; 7: 81-8, 199-205. (In German).

186. Löw I. Die Flora der Juden. Band III, Wien - Leipzig. Löwit. 1924.

187. Gezgin, D. Bitki Mitosları (Üçüncü Baskı), İstanbul: Sel Yayıncılık; 2015..( In Turkish).

188. Zorğlou B. Mandragora officinarum Hakkinda Farmakognozik ve Tarihsel Araștirmalar. Kaiseri. Erciyes Üniversitesi Eczacilik Fakültesi. 2019. (In Turkish) 189. Richardson J. A Persian, Arabic, English Dictionary. London: Cox; 1806.

190. Moore T. Lalla Rookh: Veiled Prophet of Khorassan. London: Thomas Y. Crowell \& Company; 1817.

191. Ascherson P. Nachträgliche Mittheilungen über Mandragoras. Zeit ethnol. 23:890-892. 1891. (In German).

192. Hoshimkhudzhaeva MM. Study of polysemantic phytonyms of the English, Russian and Uzbek languages in the linguoculturological aspect. Bulletin of the Chelyabinsk State University, Philology. Art Criticism 2012;67:143-46.

193. Schlosser, A. Die Sage Von Galgenmännlein Im Volksglauben Der Literatur. Münster: Druck der Theissingschen buchhandlung; 1912 (In German).

194. Waggoner, B. Norse Magical and Herbal Healing. New Haven: Troth Publications; 2011.

Page $17 / 42$ 
195. Davies O, Matteoni F. Executing Magic in the Modern Era: Criminal Bodies and the Gallows in Popular Medicine. London: Palgrave Macmillan; 2017. DOI: 10.1007/978-3-319-59519-1

195. Davies O, Matteoni F. Executing Magic in the Modern Era: Criminal Bodies and the Gallows in Popular Medicine. Cham, Switzerland: Palgrave, MacMillan; 2017.

196. Jaworskij, J. Die Mandragora im südrussischen Volksglauben. ÖZV. 1896;2:353-361. (In German).

197. Vardanian A. The Assyro-Babylonian Xumbaba and the Armenian Plant Name Xembaba. Iran and the Caucasus 1999-2000 3-4: 207-8.

198. Amasiaci A. Nenužnoe dlja neučej. Transl. Vardanian, Moscow: S.A .Nauka;1990. (In Russian). (In [102:253]).

199. Rahner H. Greek Myths and Christian Mystery. New York: Biblo and Tannen Publishers; 1963.

200. Randolph CB. The Mandragora of the ancients in folk lore and medicine, Proc. Amer. Acad. Arts Sci. 1905:40: 487-532.

201. Simoons FJ. Plants of Life, Pplants of Death. Madison: Univ of Wisconsin Press; 1998.

202. Wagstaff DJ. International poisonous plants checklist: an evidence-based reference. Boca Raton: CRC Press; 2008.

203. Topper U. Wortsammlung der Tier-und Pflanzennamen im Taschelhiyt-Berberischen von Marokko. Almogaren. 1998;29:199-214.

204. Harrak H, Lebrun M, Alaoui,MMI, Senhaji AF, Hamouda A. Vers une valorisation du savoir-faire local des oasis: cas du jus de dattes Tassabount au Maroc. Fruits, 2009;64(4):253-260.

205. Léveillé, MH. Mandragora. Flora of China. St Louis: Missouri Botanical Garden Press; 1994;17:329.

206. Politis NG. Laografika symmeikta, Vol. II. - Dimosievmata tou Kentrou erevnis tis Ellinikis Laografias No 13, Second edition. Athens: Akadimia Athinon; 1975. (In Greek).

207. Sinev IE. The history of Mandragora turkomanica (Solanaceae). Isr. J. PI. Sci. 2016:63(3):176-181.

208. Genaust H. Etymologisches Wörterbuch der botanischen Pflanzennamen. Basel and Stuttgart: Birkhäuser; 1979. (In German).

209. Gassen HG, Minol S. Die Alraune oder die Sage vom Galgenmännlein: Science \& Fiction. Biol. in uns, 2006:36(5);302-307.(In German)

210. Paxton J. Paxton's Botanical Dictionary: Comprising the Names, History, and Culture of All Plants Known in Britain; with a Full Explanation of Technical Terms. New Ed. Including All the New Plants up to the Present Year. London: Bradbury, Evans, \& Company; 1868.

211. Craig J. A New Universal, Technological, Etymological and Pronouncing Dictionary of the English Language, Embracing All the Terms Used in Art, Science and Literature (Vol. 2). London: Routledge and co.; 1852.

212. Frazer JG. Jacob and the Mandrake. Proc. Br. Acad., 1917;8: 59-79.

213.Laufer B. La mandragore. T'oung Pao/ 1917;18(1/2):1-30.

214. Royal Academy of Language -Spanish-, Web https://dle.rae.es/mandr\%C3\%A1gora accessed 22 March 2019.

215. Kluge H. Etymologisches Wörterbuch der deutschen Sprache. Ed. by Elmar Seebold. 24th revised and enlarged edition. Berlin, New York: de Gruyter; 2002.

216. Anderson RR, Goebel U, Reichmann O. Frühneuhochdeutsch arbeit und einige zugehörige Wortbildungen. Ebenbauer, A.(Hg.): Philologische Untersuchungen, Elfriede Stutz zum, 65:1-29; 1984. (In German).

217. Grimm J, Stallybrass JS. Teutonic Mythology. 4 vols. New York: Dover Publ; 1966.

218. Albeck C, Theodor J. (eds). Midrash Bereshit Rabbah. 3 vols. Jerusalem: Wahrmann; 1965.

219. Jastrow, M 1903. A Dictionary of the Targumim, the Talmud Babli, and Yerushalmi, and the Midrashic Literature. Vol. 2. London - New York: Luzac; 1903.

220. Sokoloff M. A Dictionary of Jewish Palestinian Aramaic of the Byzantine Period (DJPA)= Dictionaries of Talmud. Ramat-Gan: Midrash and Targum II; 1992.

221. Tal A. A Dictionary of Samaritan Aramaic (2 vols.). Leiden: Brill; 2000

222. Melamed EZ. Aramaic-Hebrew-English Dictionary of the Babylonian Talmud. New York: Feldheim Publishers; 2005.

223. Ibn-囚Ezra ABM, Shachter JF. The Commentary of Abraham Ibn Ezra on the Pentateuch. A. Ibn Ezra, Jay F. Shachter, Trans., Leviticus, The Commentary of Abraham ibn Ezra on the Pentateuch: vol. 3 . New York: Ktav Publishing House: 1986. 
224. Nachmanides M, Chavel CB. Commentary on the Torah: Be-reshit-Genesis. Jerusalem :Shilo publishing House; 1999.

225. Kohut A. Kritische Beleuchtung der persischen Pentateuch-Uebersetzung des Jacob Ben Joseph Tavus unter stetiger Rücksichtnahme auf die aeltesten Bibelversionen Ein beitrag zur geschichte der Bibel-Exegese von dr. Alexander Kohut. Leipzig und Heidelberg: CF Winter'sche Verlagshandlung; 1871.

226. Ginzberg L. The Legends of the Jews: From the creation to Exodus. Notes for Volumes 1 and 2. Philadelphia: Jewish Publication Society of America; 1925.

227. Wetzstein DJG. Excurse zum Hohenliedund zu Koheleth In :. Biblischer Commentar: Bd. Hoheslied und Koheleth. Delitzsch F.(ed.). 4: 437-455. Leipzig: Dörffling und Franke. 1875. (In German).

228. Elliot S. Evolution of the Dragon. New York: Library of Alexandria; 1919.

229. Yesha'aya N. Sefer Maor Ha'afela. Y. Kappakh (transl.). Jerusalem: Ha'aguda Lehatsalat Ginzey Teiman;1957. (In Hebrew).

230. Clendening L. Source Book of Medical History (vol. 621). New York: Courier Corporation; 1960.

231. Fleisher A. Fleisher Z. The fragrance of biblical mandrake. Econ. Bot. 1994; 48:243-251.

232. Bos G, Hussein M, Mensching G ,Savelsberg F. Medical Synonym Lists from Medieval Provence: Shem Tov ben Isaac of Tortosa: Sefer ha-Shimmush. Leiden: Brill; 2011.

233. Bennett B.C. Doctrine of Signatures: An explanation of medicinal plant discovery or dissemination of knowledge. Econ. Bot. 2007; 61: $246-255$.

234. Lindley J, Moore T. The Treasury of Botany: A Popular Dictionary of the Vegetable Kingdom. vol. 2. London: Longmans; 1876.

235. Keezer WS. Botanical Sources of Early Medicines. Bios. 1963;34:185-191.

236. Dumas A. The history of anaesthesia. J. Natl. Med. Assoc. 1932; 24; 6-9.

237. Gottlieb LS. In search of Nepenthe. J. Health Hum. Behav. 1962; 3:288-293.

238. Wright T. The Archaeological Album; Or Museum of National Antiquities. Wright T.(ed.). London.Chapman \& Hall; 1845.

239. Sruanjteanc' G. Erker (Songs), vol. 1, Yerevan: 1978.( In: 101:153).

240. Adams F. The genuine works of Hippocrates. 2 vols., London: Printed for the Sydenham Society; 1849.

241. Başer KHC, Honda G, Miki, W. Herb Drugs and Herbalists in Turkey. Tokyo: Stud. Cult. Islam. No. 37. Institute for the Study of Languages and Cultures of Asia and Africa; 1986.

242. Wink M. A short history of alkaloids. In: Alkaloids: Biochemistry, Ecology and Medicinal Applications. Roberts MF. (Ed.). Berlin-Heidelberg: Springer Science \& Business Media; 2013:11-45.

243. Hanuš LO, Řezanka T, Spížek J, Dembitsky VM. Substances isolated from Mandragora species. Phytochemistry 2005;66: 2408-17.

244. Hanuš LO, Dembitsky VM, Moussaieff A. Comparative study of volatile compounds in the fresh fruits of Mandragora autumnalis. Acta Chromatog. 2006;17:151-160.

245. Jackson BP, Berry MI. Mandragora taxonomy and chemistry of the European species, In: The biology and taxonomy of the Solanaceae, Linnean Society Symposium Series, Hawkes JG, Lester RN, Skelding AD.(eds). London: Academic Press; 1979:505-512.

246. Al-Khalil S. Al Kofahi A. The chemical constituents of Mandragora autumnalis. Alexand. J. Pharm. Sci. 1996;10:135-138.

247. Schlesinger D, Rikanati RD, Volis S, Faigenboim A, Vendramin V, Cattonaro F, Hooper M, Oren E, Taylor M, Sitrit, Y, Inbar, M. Alkaloid chemodiversity in Mandragora spp. is associated with loss-of-functionality of MoH6H, a hyoscyamine 63-hydroxylase gene. PI. Sci. 2019;283:301-310.

248. Bosse-Griffith K. Amarna Studies and Other Selected Papers. Fribourg, Switzerland / Göttingen, Germany: University Press. Vandenhoeck Ruprecht; 2001

249. Folkard R. Plant Lore, Legends, and Lyrics: Embracing the Myths, Traditions, Superstitions, and Folk-lore of the Plant Kingdom. London: Sampson Low, Marston, Searle, and Rivington; 1892.

250. Weil MS. Magiferous plants in medieval English herbalism. Doctoral dissertation. Department of History and the Faculty of the Graduate School of the University of Kansas. 2009. http://humboldt-dspace.calstate.edu/bitstream/handle/2148/500/magi_plants_h.pdf?sequence=1 accessed 20 March 2019.

251. Trevelyan M. Folk-lore and Folk Stories of Wales. London: Elliot Stock; 1909.

252. Thompson CJS. The Mystic Mandrake. London: Rider; 1934

253. Buckland R. Signs, Symbols and Omens: An Illustrated Guide to Magical and Spiritual Symbolism. St Paul. Minnesota Llewellyn: Worldwide; 2003. 
254. Jurj G. Mandragora. Bul. Soc. Rom. Homeopat. 1998;2:22-27.

255. Emboden W. Narcotic Plants, Hallucinogens, Stimulants, Inebriants and Hypnotics-Their Origins and Uses. London: Littlehampton Book Services Ltd.; 1972.

256. Abraham HD, Aldridge AM, Gogia P. The psychopharmacology of hallucinogens. Neuropsychopharmacology 1996;14(4):285-298.

257. Laza Palacios M. El ungüento de las brujas. Gibralfaro. Revista de estudios malagueños. Año III, num. 3. 1953; 163-170. (In Spanish).

258. Ostling M. Babyfat and BellCEonna: Witches' Ointment and the Contestation of Reality. Magic Ritual Witchcr. 2016; 11:30-72.

259. Hildegard Von Bingen. Physica The Complete English Translation of Her Classic Work on Health and Healing. Throop P. (transl.). Trochester:Art Healing Press; 1998.

260. Lee MR. The Solanaceae II: the mandrake (Mandragora officinarum); in league with the Devil. J. Roy. Coll. Physic. Edin. 2006;36:278-285.

261. Chéruel A. Dictionnaire historique des instititons moerus et coutumes de la France. 7th Ed. vol. 2. Paris: Librairie Hachette; 1899.

262. Sébillot P. Le Folk-lore de France. vol. 3. Paris: Éditions G.P. Maisonneuve et Larose; 1969 (In French).

263. Frazer JG. Folk-Lore in the Old Testament. vol 2. London: Macmillan; 1918

264. Crichfield, G., 1983. The Alchemical Magnum Opus In Nodier's La Fee Aux Miet-tes". Ninet Century Fr Stud, 11(3/4), pp.231-245. (In French).

265. Flavius J. The War of the Jews. Transl. W. Whiston. New York: Simon and Schuster; 2014.

266. Artemi. Momoirs of the Life of Artemi of Wagarschapet. London: Treuttel and Würtz, Treuttel Jun. and Richter. 1822.

267. Bajela - Farroki MH. Creation of mankind in Asaiia myths. In: The Communication of Ideas. Yadava JS, Gautam V. (eds.). Delhi: International Congress of Anthropological and Ethnological Sciences. Concept Publishing Company. 1980; 3:11-16.

268. Cowan JM. A botanical expedition to Persia. Bull. Misc. Inform. Kew. , 1930; 2:.49-68.

269. Arber A. Herbals: Their Origin and Evolution. Cambridge: Cambridge University Press. 1938.

270. Roger E. La Terre Saincte, ou, Description topographique tres-particuliere des Saincts Lieux \& de la Terre de Promission. Paris: Chez A. Bertier; 1764. (In French).

271. Hardwick C. Traditions, Superstitions, and Folklore, (chiefly Lancashire and the North of England:) Their Affinity to Others in Widely distributed Localities; Their Eastern Origin and Mythical Significance. London; A. Ireland; 1872.

272. Bosner W. The medical background of Anglo-Saxon England. London: The Wellcome; 1963.

273. Rowe K. Dead Hands: Fictions of Agency, Renaissance to Modern. Stanford: Stanford University Press; 1999.

274. Baker, F. Anthropological notes on the human hand. Am. Anthropolo., 1888; 1(1):51-76.

275. Eliade M. Gayōmart et la Mandragore. In: Ex Orbe Religionum, Altera P. (ed.). Leiden: Brill; 1972:65-74.

276. Albrile E. Hypnotica Iranica, Zoroastrianism ecstasy in the West. Aram. In: Abouzayd S. (ed.). Zoroastrianism in the Levant and the Amorites. Aram. 2014;26:181-187. https://docplayer.net/119328891-Hypnotica-iranica-zoroastrian-ecstasy-in-the-west.html. acccessed 18 Feb 2020.

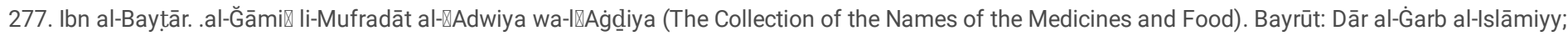
1992. (In Arabic).

278. Pliny. Natural History. Rackham H. (transl.). Loeb Classical Library. London: William Heinemann: 1938-1962.

279. Dierbach JH. Flora mythologica oder Pflanzenkunde in Bezug auf Mythologie und Symbolik der Griechen und Römer: ein Beitrag zur ältesten Geschichte der Botanik, Agricultur und Medicin. Frankfurt am Main: Johann David Sauerländer; 1833.

280. Apollonius Rhodius. The Argonautica. (trans. R. C. Seaton). London: Loeb Classical Library. William Heinemann: G.P. Putnam's Sons. 1930.

281. Clark RJ. A Note on Medea's Plant and the Mandrake. Folklore, 1968;79(3):227-231.

282. Forbes TR. Medical lore in the bestiaries. Med. Hist., 1968;12(3):245-253.

283. Diekstra FN. The Physiologus, the bestiaries and medieval animal lore. Neophilologus, 1985;69(1): 142-155.

284. Lang A. Customs and Myths. Price D. (ed.).London: Longmans, Green and Co.; 1884. 


\section{Tables}

Table 1: A. Derivatives of "generic" names: A1. Mandragora; A2. Alraune; A3. Yabroukh. 


\begin{tabular}{|c|c|c|c|}
\hline $\begin{array}{l}\text { Language / } \\
\text { Sub- } \\
\text { category }\end{array}$ & Name & $\begin{array}{l}\text { Ethnic } \\
\text { Transcription }\end{array}$ & Selected References \\
\hline \multicolumn{4}{|l|}{ A1 } \\
\hline Albanian & $\begin{array}{l}\text { mandragora, madëronë, } \\
\text { matergonë }\end{array}$ & & Albanian Bible [12:163] \\
\hline Armenian & [mandragora] & 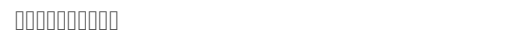 & {$[48: 1268]$} \\
\hline Bulgarian & [mandragora] & тандрагора & [49:36]; [50]; [51:394] \\
\hline Catalan & $\begin{array}{l}\text { mandràgola, } \\
\text { mandràgora }\end{array}$ & & {$[46: 190]\left(13^{\text {th }} c.\right)$.} \\
\hline Corsican & tramangula & & {$[52: 471]$} \\
\hline Dutch & mandragers kruit & ["Mandrake herb"] & {$[53: 11] ;[31: 45]$} \\
\hline Dutch & mandragore & & [31:45] \\
\hline English & $\begin{array}{l}\text { mandrake } \\
\text { Spelling variations: } \\
\text { mandrage, } \\
\text { mandrag, mandragge, } \\
\text { mendrage }\end{array}$ & & [54:51]; [55:322]; [56:66]; [28:71]; [31:43]; [30:333] \\
\hline French & mandrigoula & & [28:71]; [31:44] \\
\hline Georgian & [mandragora] & 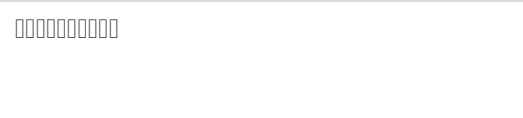 & $\begin{array}{l}\text { Rainer Bussmann (Pers. Comm } \\
\text { 25.1.20). }\end{array}$ \\
\hline Greek & $\begin{array}{l}\text { [mandragora] } \\
\text { Spelling } \\
\text { variations: [mandragúda, } \\
\text { mandragúdas, } \\
\text { matragúra, mantragúras, } \\
\text { mandragúri, } \\
\text { mandraúla, } \\
\text { mandraúna, } \\
\text { mentragúra] }\end{array}$ & 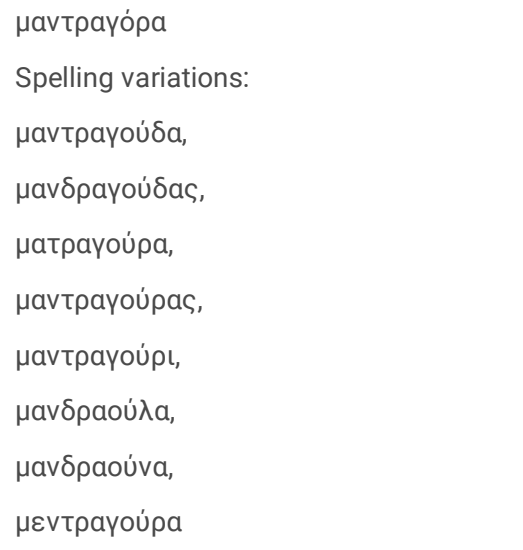 & [57:173]; [58:2509]; [59: 433,437]; [60:408] \\
\hline Greek & [mandragóras] (m) & 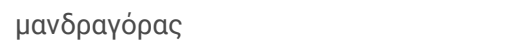 & [45:4,75]; [58:2509]; [59:440]; [61:9,8,8]; [62:600] \\
\hline Hungarian & nadraguyla & & [63: I,537]; [64:55] \\
\hline Italian & $\begin{array}{l}\text { mandragora } \\
\text { Spelling variations: } \\
\text { mandræela, } \\
\text { mandràhura, } \\
\text { mandràgura, mandràura, } \\
\text { mandulàgrona, } \\
\text { mandràgura }\end{array}$ & & [65]; [28:71] \\
\hline Polish & matryguna, matrygan, & & {$[12: 170]$} \\
\hline
\end{tabular}

Page 22/42 


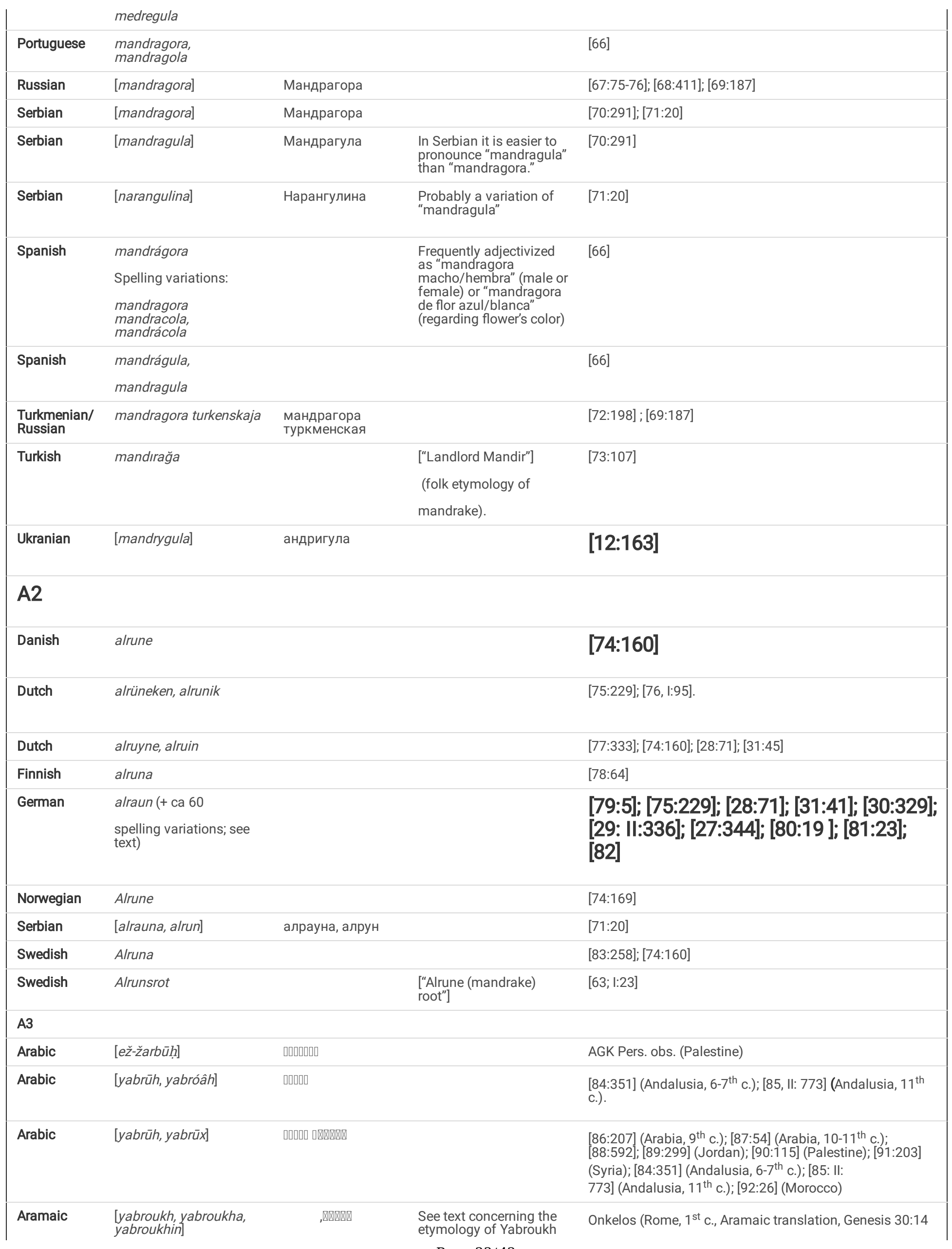

Page 23/42 


\begin{tabular}{|c|c|c|c|c|}
\hline & & 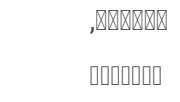 & & [93:14]); Babylonian Talmud [94] \\
\hline Bengali & [yebruj] & & & [28:71] \\
\hline Farsi & $\begin{array}{l}\text { [sāyeh- } \\
\text { boruj] }\end{array}$ & Q & $\begin{array}{l}\text { Derivative } \\
\text { of Yabroukh } \\
\text { in Aramaic } \\
\text { (see text) }\end{array}$ & {$[95: 645]$} \\
\hline Turkish & Yebrûh & & $\begin{array}{l}\text { See text concerning the } \\
\text { etymology of Yabroukh }\end{array}$ & [73:107]; [41:124]; [96:232-234] \\
\hline Turkish & yebrûhu's-sanem & & Idol's Yabroukh & [97:1391]; [73:107]; [41:124]; [96:232-234] \\
\hline
\end{tabular}

Table 2: B. Morphological characteristics: B1. Root (Anthropomorphism); B2. Leaves, fruits, and seeds; B3. Similarity to other plants. 


\begin{tabular}{|c|c|c|c|c|}
\hline $\begin{array}{l}\text { Language/ } \\
\text { Sub- } \\
\text { category }\end{array}$ & Name & $\begin{array}{l}\text { Ethnic } \\
\text { Transcription }\end{array}$ & Meaning & Selected References \\
\hline \multicolumn{5}{|l|}{ B1 } \\
\hline Arabic & $\begin{array}{l}\text { [šağarat aṣ- } \\
\text { șanam] }\end{array}$ & Q & $\begin{array}{l}\text { Lit. [“The image's (idol) } \\
\text { tree," }\end{array}$ & [88:14]; [98, IV:443]; [99] \\
\hline & & & "A human (shaped) tree"] & \\
\hline Armenian & [marda-khot] & 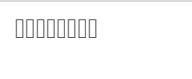 & $\begin{array}{l}\text { Literarily [“Human (-like) } \\
\text { plant"] }\end{array}$ & [100:106]; [101:152]; [102:251] \\
\hline Czech & mužijk, mužicek & & [“Little man"] & [103:43]; [104:289]; [12:166] \\
\hline Czech & strýček & & [“Uncle"] & [104:289] \\
\hline Danish & dukkeurt & & [“Doll's herb"] & [27:344] \\
\hline Dutch & aardmannetje & & [“Little earth man”] & [76, I:95]; [31:45]; [105:35] \\
\hline Dutch & alruinmanntje & & [“Mandrake's little man”] & [106:29] \\
\hline Dutch & $\begin{array}{l}\text { mandragora } \\
\text { mannetje }\end{array}$ & & [“Mandrake's man”] & [28:71]; [31:45] \\
\hline Dutch & wortelmannetje & & [“Little root man”] & [107:63]; [31:45] \\
\hline Dutch & wortelmensch & & [“Root man"] & [108:541]; [31:45] \\
\hline English & ladylin & & [“Little Lady"] & [29, II:336]; [109:70] \\
\hline English & root of life & & $\begin{array}{l}\text { Due to the hallucinogenic } \\
\text { effects? }\end{array}$ & [30:334] \\
\hline English & womandrake & & & [110:343]; [56:66]; [109:70]; [29, II:336] \\
\hline Farsi & [mardom-gīyāh] & 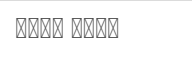 & ["Plant of the people"] & [100:106]; [111:2]: [101:152] \\
\hline French & homme planté & & [“Planted man”] & [28:71]; [31:43]; [29:336] \\
\hline French & plante humaine & & [“Human Plant”] & [112:225]; [28:71]; [31:44]; [113:8] \\
\hline German & $\begin{array}{l}\text { alraunmännchen, } \\
\text { alruyn manneken }\end{array}$ & & ["Alrun man"] & {$[114: 15]$} \\
\hline German & atzelmännchen & & [“Doll”] & [115:164]; [30:330] \\
\hline German & atzmann & & ["'"Doll," “Puppet”] & [31]; [30]; [114:15] [81:23] \\
\hline German & $\begin{array}{l}\text { erdmännchen, } \\
\text { erdmännlein }\end{array}$ & & $\begin{array}{l}\text { [“Little earth } \\
\text { man"]/[“Earth mannekin”] }\end{array}$ & \\
\hline German & erdweibchen & & [“Little earth woman”] & [117:185]; [116:25] \\
\hline German & $\begin{array}{l}\text { mandlwurz, } \\
\text { mandelwurz }\end{array}$ & & [“Little root-man"] & [118:355]; [119:137]; [120:113]; [2:1138] \\
\hline German & menschenwurzel & & [“Human's root”] & \\
\hline
\end{tabular}




\section{[114:15]; [81:23]}

\begin{tabular}{|c|c|c|c|c|}
\hline Greek & [anthropómorphos] & 『vөршпо́норчос & $\begin{array}{l}\text { ["Human-shaped"] Due to } \\
\text { its anthropomorphic } \\
\text { roots] }\end{array}$ & {$[45: 4,75]$} \\
\hline Greek & [paidi] & $\pi a ı \delta i$ & $\begin{array}{l}\text { "Child" ([may be } \\
\text { (because of its small, } \\
\text { child-shaped root; less } \\
\text { probable is because it } \\
\text { may induce fertility)] }\end{array}$ & {$[59: 442]$} \\
\hline Greek & [arkánthropos] & 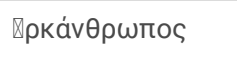 & $\begin{array}{l}\text { "Bear-man shaped" [due } \\
\text { to its fat/hairy roots] }\end{array}$ & [62:600]; [58:2509]; [121:357] \\
\hline Latin & antropophora & & $\begin{array}{l}\text { ["Human-shaped"; } \\
\text { botanical Latin] }\end{array}$ & $[45: 4,75])$ \\
\hline Latin & semihomo & & [“Half human”] & {$[45: 4,75]$} \\
\hline Polish & męzyk & & [“Male"] & {$[12: 164]$} \\
\hline Turkish & adamkökü & & [“Man root"] & [122:268]; [73:107]; [90:232-234]; [41:124] \\
\hline Turkish & adamotu & & [“Man plant”] & [123:21]; [124:2] \\
\hline Turkish & insan kökü & & [“Person root”] & [73:107]; [28:71]; [93:232-234]; [41:124] \\
\hline Turkish & insan otu & & [“Person plant”] & [73:107]; [123:21]; [124:2] \\
\hline \multicolumn{5}{|l|}{ B2 } \\
\hline Arabic & [fākihat al-gurāb] & 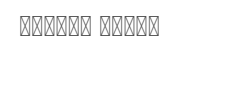 & $\begin{array}{l}\text { ["Raven's fruit"] } \\
\text { (the birds like this fruit) }\end{array}$ & [125:624-625] (Andalusia, $13^{\text {th }}$ c.) \\
\hline Arabic & $\begin{array}{l}\text { [sābizāj, șābizāj } \\
\text { ] }\end{array}$ & 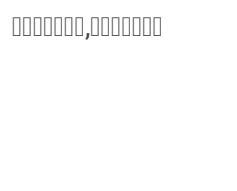 & $\begin{array}{l}\text { From Farsi: } \\
\text { šā(h)- 'black' (cf. šāah-tūt) } \\
\text { and bīzak 'seed,' 'grain' } \\
\text { meaning “( (a plant with) } \\
\text { black (dark) seeds" }\end{array}$ & [84:351] (Andalusia 6-7 ${ }^{\text {th }}$ c.); [126:219]; [100:106] (Syria) \\
\hline Arabic & [/uffāh] & प्राप्रा & $\begin{array}{l}\text { "The burning } \\
\text { (or emitting a good } \\
\text { odour) fruit. Name } \\
\text { relates only to the fruit of } \\
\text { the mandrake. }\end{array}$ & $\begin{array}{l}\text { [127, II:279] (Iran, } 10^{\text {th }} \text { c.); [86:107] (Arabia, } 9^{\text {th }} \text { c.); } \\
{\left[85, \text { II:774] (Andalusia, } 11^{\text {th }} \text { c.); [88:592]; [41:121]; [128:242] }\right.} \\
\text { (Arabia, } 9^{\text {th }} \text { c.); } \\
\text { [129:250] (North Africa); [130:36] (Turkey); AGK Pers. obs. } \\
\text { (Palestine) }\end{array}$ \\
\hline Armenian & [loshtak, loštak] & 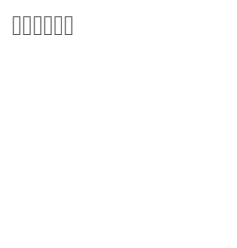 & $\begin{array}{l}\text { Loshtak means, in } \\
\text { Armenian, literally "ear" } \\
\text { Mandrake is called } \\
\text { Loshtak due to the fact } \\
\text { that "the leaf is large and } \\
\text { with many ridges like an } \\
\text { ear." (Garnik Asatrian, } \\
\text { Pers. com. 30.10.19) }\end{array}$ & [63, I:537]; [101:154] \\
\hline Farsi & $\begin{array}{l}\text { [šā(h)bīzak } \\
\text { Spelling variants: } \\
\text { sābisaj / šbizak / } \\
\text { sbysq, šbysk] }\end{array}$ & 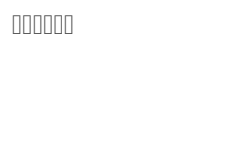 & $\begin{array}{l}\text { Plant with black seeds, } \\
\text { see above (Also } \\
\text { Belladonna) }\end{array}$ & $\begin{array}{l}\text { [130:36]; [95:688]; } \\
{[100: 106]}\end{array}$ \\
\hline Greek & $\begin{array}{l}\text { [avgoulátsa/ } \\
\text { avgoudátsa] }\end{array}$ & 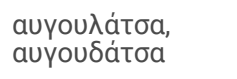 & $\begin{array}{l}\text { ["Bearing little egg- } \\
\text { shaped fruits"] }\end{array}$ & [59:430] \\
\hline Greek & [chondrovotáni] & Xovtрoßotávı & $\begin{array}{l}\text { ["Fat herb"] (probably due } \\
\text { to its large leaves or its } \\
\text { fat taproot)] }\end{array}$ & [59:439] (Lakonia) \\
\hline Greek & [kourouniá] & koupouviá & $\begin{array}{l}\text { [“Crow nest-shaped”] } \\
\text { (leaves) }\end{array}$ & $\begin{array}{l}\text { [59:433-434] (Nisyros and } \\
\text { Leros islands) }\end{array}$ \\
\hline
\end{tabular}




\begin{tabular}{|c|c|c|c|c|}
\hline Greek & [megalovotáni] & $\mu \varepsilon ү a \lambda$ & $\begin{array}{l}\text { [“Large herb"] (due to its } \\
\text { large leaves or fat } \\
\text { taproot). }\end{array}$ & [59:439] (Lakonia) \\
\hline Greek & [papútsa] & папои́тба & [“Shoe-shaped”] (leaves) & [59:440] (Cyprus) \\
\hline Serbian & [nadliška] & Надлишка & $\begin{array}{l}\text { "Nad" means over, above, } \\
\text { and "liška" means leaf; } \\
\text { probably the word means } \\
\text { something stronger or } \\
\text { more important than leaf } \\
\text { (which is close to the root } \\
\text { in the mandrake) or } \\
\text { could also emphasize the } \\
\text { fruit ("above the leaf") }\end{array}$ & [71:20] \\
\hline Serbian & [veliko zelje] & ьелико зеље & $\begin{array}{l}\text { "Veliko" means great, } \\
\text { large, big; "zelje" means } \\
\text { greens or herb. The word } \\
\text { could implicate "a great } \\
\text { herb" because of its } \\
\text { relatively large (long) } \\
\text { leaves. }\end{array}$ & [71:20] \\
\hline Serbian & [vodopić] & ьодопић & $\begin{array}{l}\text { "Voda" means water, } \\
\text { "piti" means to drink; } \\
\text { literally "vodopić" is one } \\
\text { who drinks water; could } \\
\text { be linked to shiny intense } \\
\text { green leaves (?) }\end{array}$ & [71:20] \\
\hline Serbian & $\begin{array}{l}\text { [veliko zelje } \\
\text { / velje zelje] }\end{array}$ & ьелико зеље & $\begin{array}{l}\text { "Veliko" means great, } \\
\text { large, big; "zelje" means } \\
\text { greens or herb. The word } \\
\text { could implicate "a great } \\
\text { herb" because of } \\
\text { relatively large (long) } \\
\text { leaves. }\end{array}$ & [71:20] \\
\hline Serbian & [vodopic] & ьодопић & $\begin{array}{l}\text { "Voda" means water, } \\
\text { "piti" means to drink; } \\
\text { literally "vodopić" is one } \\
\text { who drinks water; could } \\
\text { be linked to shiny intense } \\
\text { green leaves (?) }\end{array}$ & [71:20] \\
\hline Spanish & lirios & & $\begin{array}{l}\text { [“Lily flower”] } \\
\text { (resemblance to lily } \\
\text { flower) }\end{array}$ & [131:175] \\
\hline Turkish & beş damar otu & & [“Five-veined plant”] & [41:124] (North Cyprus) \\
\hline Turkish & lüffâh & & $\begin{array}{l}\text { Luffah (Mandrake's fruit } \\
\text { in Arabic) }\end{array}$ & [41:124]; [87:293,340] \\
\hline Turkish & lüffâh-ı berry & & Wild luffah (see Lüffâh) & [41:124] \\
\hline \multicolumn{5}{|l|}{ B3 } \\
\hline Arabic & [tuffāḥ al-barr] & Q & [“Wild apple”] & [132] \\
\hline Arabic & [tuffāḥ bittanžān] & 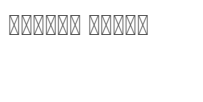 & [“Eggplant's apple”] & $\begin{array}{l}\text { A local name in the Galilee. Israel } \\
\text { (SAH Pers. Obs) }\end{array}$ \\
\hline French & $\begin{array}{l}\text { belladone sans } \\
\text { tige }\end{array}$ & & $\begin{array}{l}\text { [“Belladonna without a } \\
\text { stem”] (The former name } \\
\text { of Mandragora acaulis) }\end{array}$ & [31:43]; [28:71]; [29:336] \\
\hline French & pomme Terrestre & & [“Earth's apple”] & [112:225]; [133:184]; [113:8] \\
\hline German & borchart & & $\begin{array}{l}\text { Burcher = a popular } \\
\text { name for Atropa } \\
\text { belladonna (Hambel } \\
\text { 2002:330) }\end{array}$ & $\begin{array}{l}\text { [75:229]; [134, III:53]; } \\
\text { [31:41]; [30:330] }\end{array}$ \\
\hline German & erdapfel, ertapfel & & [“Earth's apple”] & $\begin{array}{l}\text { [83; 258]; [118:355]; [119:137]; [75:22]; [134, III :53]; } \\
\text { [31:41]; [30:331] }\end{array}$ \\
\hline German & $\begin{array}{l}\text { malzapfel, } \\
\text { maltzapfel, } \\
\text { melzlh apfel }\end{array}$ & & $\begin{array}{l}\text { Seems to be a } \\
\text { corruption/translation of } \\
\text { 'pomum macianum' }\end{array}$ & $\begin{array}{l}\text { [136, I:2021]; [135:23]; } \\
\text { [137:84]; [134, III :53]; [81:23] }\end{array}$ \\
\hline
\end{tabular}




\begin{tabular}{|c|c|c|c|c|}
\hline Greek & [mala silvestria] & $\begin{array}{l}\mu \alpha \dot{\alpha} \lambda a \\
\sigma \iota \lambda \beta \varepsilon \dot{\varepsilon} \sigma \tau \rho ı\end{array}$ & [“Wild apples"] & {$[45: 4,75]$ (Romans in Greece) } \\
\hline Greek & [mala terrestrial] & 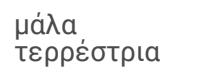 & [“Earth's apples"] & {$[45: 4,75]$} \\
\hline Greek & [milopeponiá] & 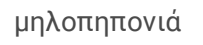 & [“Apple-melon tasting”] & [62:600]; [121:357] (Cyprus); [59:440]; [60:408] \\
\hline Greek & [miliákos] & $\mu \eta \lambda ı$ ı́коৎ & [“Apple-like”] & [60:408]; [58] \\
\hline Greek & $\begin{array}{l}\text { Өpıбакіа (f.) } \\
\text { / Өрıбакіаৎ (m) }\end{array}$ & 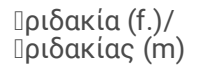 & [“Lettuce-looking plant”] & {$[45: 4,75] ;[61: 9,8,8]$} \\
\hline Latin & $\begin{array}{l}\text { malum terrae, } \\
\text { malus terrae }\end{array}$ & & [“Earth's apple”] & [84:351] (Andalusia, 6-7 $-^{\text {th }}$ c.); [79:6] (Spain). \\
\hline Latin & mala terrestria & & [“Land apple”] & {$[45: 4,75]$} \\
\hline Latin & thridakía, thridaks & & $\begin{array}{l}\text { ["A kind of lettuce"] } \\
\text { Due to the leaf shape? }\end{array}$ & {$[45: 4,75] ;[138: 419]$} \\
\hline Serbian & [divlja jabučica] & $\begin{array}{l}\text { Дивља } \\
\text { Јабучица }\end{array}$ & $\begin{array}{l}\text { "divlja" means wild } \\
\text { and "jabučica" means } \\
\text { small apple. }\end{array}$ & [71:20] \\
\hline Slovak & Pěkná jablečka & & ["beautiful apple"] & [139:359] \\
\hline Spanish & manzana de tierra & & [“Earth's apple"] & [131:192] \\
\hline Spanish & acelgón, acelgones & & $\begin{array}{l}\text { ["Chard"] (due to the } \\
\text { leaves resembling this } \\
\text { plant) }\end{array}$ & [66] \\
\hline Spanish & $\begin{array}{l}\text { berengenilla, } \\
\text { berenjenilla }\end{array}$ & & [“ little eggplant”] & [66] \\
\hline Spanish & berenjena mora & & [“Moorish eggplant”] & {$[66]$} \\
\hline Spanish & lechuguilla & & [“Small lettuce"] & [66] \\
\hline Spanish & tomatico & & ["Small tomato"] & {$[66]$} \\
\hline Spanish & uva de moro & & ["Moorish grape"] & {$[66]$} \\
\hline Turkish & lüffâh-ı berri & & [“Earth loofah"] & {$[41: 124]$} \\
\hline Turkish & toskafa kavunu & & $\begin{array}{l}\text { ["Butting head melon"] } \\
\text { (because it looks like a } \\
\text { head that butts) }\end{array}$ & [73:107]; [123] \\
\hline Turkish & yer elması & & [“Earth apple”] & [73:73]; [123:21] \\
\hline Turkish & yer yenidünyası & & [“Earth's loquat”] & [41:124]; [123:21] \\
\hline
\end{tabular}

Table 3: C. Pharmacological characteristics and medicinal uses: C1. Medicinal properties; C2. Narcotic, hallucinogenic, poisonous; C3. Aphrodisiac. 


\begin{tabular}{|c|c|c|c|c|}
\hline $\begin{array}{l}\text { Language/ } \\
\text { Subcategory }\end{array}$ & Name & $\begin{array}{l}\text { Ethnic } \\
\text { Transcription }\end{array}$ & Meaning & Selected References \\
\hline \multicolumn{5}{|l|}{ C1 } \\
\hline Arabic & [abu salām] & 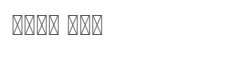 & $\begin{array}{l}\text { [“Father of } \\
\text { health"] }\end{array}$ & [145:709] \\
\hline Arabic & [ 『abd es-salām] & 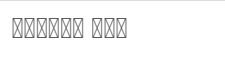 & $\begin{array}{l}\text { [“The servant of } \\
\text { health”] }\end{array}$ & [122:268] \\
\hline Armenian & $\begin{array}{l}\text { [t'agawor amen } \\
\text { Xotic] }\end{array}$ & 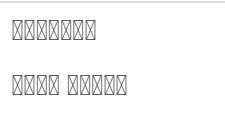 & $\begin{array}{l}\text { [“King of all } \\
\text { (every) grasses } \\
\text { (and forbs)”], see } \\
\text { text }\end{array}$ & {$[141: 389] ;[101: 153]$} \\
\hline German, Old & $\begin{array}{l}\text { ârzat uvûrze, arzanwurt, } \\
\text { arzatwurz }\end{array}$ & & [“Doctor's root”] & $\begin{array}{l}\text { [75:229]; [137:93]; [134, III :53]; [31:41]; [114:330]; [30:330]; } \\
\text { [142:38] }\end{array}$ \\
\hline German & $\begin{array}{l}\text { heilmännchen, } \\
\text { heilmännlein }\end{array}$ & & $\begin{array}{l}{[\text { "Healing }} \\
\text { male"]/healing } \\
\text { mannikin }\end{array}$ & {$[120: 113] ;[31: 41] ;[81: 23]$} \\
\hline Greek & [fistulóriza] & 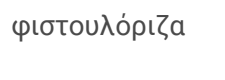 & $\begin{array}{l}\text { [“Fistula-healing } \\
\text { root"] }\end{array}$ & [143:331]; [59:427,435] \\
\hline Greek & [fistulóchorto] & рібтоихо́хорто & $\begin{array}{l}\text { [“Fistula-healing } \\
\text { root”] }\end{array}$ & [59:445] \\
\hline Serbian & Bunovina & Буновина & $\begin{array}{l}\text { Root of word is } \\
\text { "bunilo" } \\
\text { meaning } \\
\text { delirium, } \\
\text { madness }\end{array}$ & [71:20]; [70:291] \\
\hline Turkish & Ebîselâm & & $\begin{array}{l}\text { [“Father of } \\
\text { health"] }\end{array}$ & [41:124]; [124:2] \\
\hline Turkish & hastalık otu & & $\begin{array}{l}\text { [“Sickness } \\
\text { plant"] }\end{array}$ & [41:124] (North Cyprus). \\
\hline \multirow[t]{2}{*}{ Turkish } & \multirow[t]{2}{*}{ kankurutan } & & ["Blood dryer"] & [144:334]; [73:107]; [28:71]; [41:124]; [123:21] \\
\hline & & & $\begin{array}{l}\text { (because it is } \\
\text { believed that it } \\
\text { stops } \\
\text { bleeding; see } \\
\text { text) }\end{array}$ & \\
\hline \multicolumn{5}{|l|}{$\mathrm{C} 2$} \\
\hline Dutch & doodkruid & & [“Death's herb”] & [83:258]; [28:71] \\
\hline Dutch & slaapappel & & [“Sleep's apple”] & [145:263]; [146:940] \\
\hline Dutch & slaapkruid & & [“Sleep's herb”] & [146:940] \\
\hline English & brain thief & & & [109:70]; [147:169]; [148:3] \\
\hline English & divine root & & $\begin{array}{l}\text { May be due to } \\
\text { its } \\
\text { hallucinogenic } \\
\text { effect. }\end{array}$ & [30:331] \\
\hline English & fool's apple & & $\begin{array}{l}\text { May be due to } \\
\text { its } \\
\text { hallucinogenic } \\
\text { effect. }\end{array}$ & [149:316] \\
\hline Gaelic & codalian & & [“Sleep apple”] & [83:258]; [150:139] \\
\hline \multirow[t]{2}{*}{ German } & doilwurz & & [“Mad root”] & [75:229]; [134, III :53]; [120:113]; [31:41]; [30:331]; [114:15] \\
\hline & $\begin{array}{l}\text { Spelling variations: doilworz } \\
\text { dolwortz, dollwurz, tollwurtz, } \\
\text { dilwurz }\end{array}$ & & & \\
\hline German & dollblume & & [“Mad flower"] & [81:23] \\
\hline German & schlafbeere, schlafbeer & & [“Sleep berry"] & [30:334]; [81:23]; [31:42] \\
\hline German & tollkraut südliches & & $\begin{array}{l}\text { [“Southern mad } \\
\text { herb"] }\end{array}$ & [119:137]; [31:42] \\
\hline \multirow[t]{2}{*}{ German } & \multirow[t]{2}{*}{ schlafapfel, } & & [“Sleep apple”] & \multirow[t]{2}{*}{ [150:693]; [119:137]; [135:23]; [134, III:53]; [31:42]; [30:334]; [81:23] } \\
\hline & & & Page 29/42 & \\
\hline
\end{tabular}


schlaf-aepffel

\begin{tabular}{|c|c|c|c|c|}
\hline German, Old & twalm, tuualm & & [“Sleep"] & [134, III :53]; [31:42] \\
\hline Greek & [alítis] & $\nabla \lambda \circ \otimes \tau ı \varsigma$ & $\begin{array}{l}\text { ["deceiving, } \\
\text { alluring, } \\
\text { seductive"] }\end{array}$ & {$[45: 4,75]$} \\
\hline Greek & [ippóflomos] & เтாо́ $\varphi \lambda \omega \mu о \varsigma$ & $\begin{array}{l}\text { [“Driving horses } \\
\text { dizzy”] }\end{array}$ & [59:446]. \\
\hline Greek & [mórion] & $\mu \dot{\omega} \rho{ }^{\prime} о v$ & $\begin{array}{l}\text { ["Stupefying } \\
\text { plant"] }\end{array}$ & {$[45: 4,75] ;[61: 9,8,8]$} \\
\hline Greek & [trellóchortaro] & 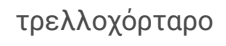 & ["Madness herb"] & [59:439] \\
\hline Greek & [vomvóchylos] & 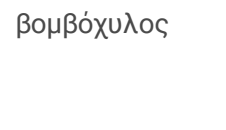 & $\begin{array}{l}\text { ["Humming- } \\
\text { inducing juice"; } \\
\text { "intoxication- } \\
\text { inducing juice" }\end{array}$ & {$[45: 4,75]$} \\
\hline Greek & [rigaléos] & 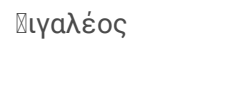 & $\begin{array}{l}\text { "Shiver-inducing, } \\
\text { thrilling" }\end{array}$ & {$[45: 4,75]$} \\
\hline Hungarian & Bolondfü & & ["Fool's grass"] & [152:41] \\
\hline Spanish & cerezas de sapo & & $\begin{array}{l}\text { ["Toad cherries"] } \\
\text { May be "toad" } \\
\text { due to its } \\
\text { poisonous effect }\end{array}$ & {$[66]$} \\
\hline \multicolumn{5}{|l|}{ C3 } \\
\hline Arabic & [Qarūsallı] & 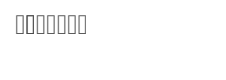 & $\begin{array}{l}\text { Dininutive of ["a } \\
\text { bride"] }\end{array}$ & [125:624-625] (Andalusia, $13^{\text {th }} \mathrm{c}$.) \\
\hline Arabic & [habb at-taهlīf] & Q & $\begin{array}{l}\text { ["The fruit that } \\
\text { gets the lovers } \\
\text { close"] }\end{array}$ & [125:624-625] (Andalusia, $13^{\text {th }} \mathrm{c}$.) \\
\hline Arabic & [/uهba mutallaqa] & 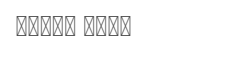 & $\begin{array}{l}\text { [“The } \\
\text { expelled bride"] }\end{array}$ & [99] \\
\hline Arabic & $\begin{array}{l}\text { [/u®ba } \\
\text { mu'allaqa] }\end{array}$ & Q & $\begin{array}{l}\text { ["The dependent } \\
\text { bride"] (lit. "The } \\
\text { married bride") }\end{array}$ & [99] \\
\hline
\end{tabular}

\begin{tabular}{|c|c|c|c|}
\hline Danish & [kærlighedsæble] & [“Love apple”] & [153:81] \\
\hline Farsi & $\begin{array}{l}\text { [mehr gīyah, } \\
\text { mihrgiāh] }\end{array}$ & $\begin{array}{l}\text { [“Plant of love”] } \\
\text { (Meher = } \\
\text { affection, } \\
\text { gîah=grass) }\end{array}$ & [154: 6 note 4]; [95:152] \\
\hline Finnish & lemmenmarja & [“Love berry”] & {$[155: 261]$} \\
\hline $\begin{array}{l}\text { German } \\
\text { (old) }\end{array}$ & chindelina wurz & $\begin{array}{l}\text { [“Little child's } \\
\text { root”] } \\
\text { (see text) }\end{array}$ & [156:118]; [31:41] \\
\hline German & kindleinkraut & ["Child herb"] & \\
\hline German & liebesapfel & [“Love apple”] & \\
\hline
\end{tabular}




\begin{tabular}{|c|c|c|c|c|}
\hline German & liebeswurz, liebeswurzel & & [“Love herb"] & {$[114 \cdot 15] \cdot[81 \cdot 23]$} \\
\hline Greek & [sernikobótano] & бєрvıкоßо́tavo & $\begin{array}{l}\text { ["Male-birth- } \\
\text { inducing herb"] }\end{array}$ & [59:441] \\
\hline Hebrew & [duda'eem] & 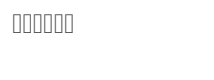 & 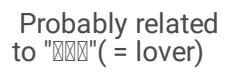 & Genesis $30: 14-16$; Song of Songs 7:13 \\
\hline Turkish & ayıkotu & & "Vivacity grass" & [157]:128 \\
\hline Turkish & muhabbet otu & & [“Love plant”] & [73:107]; [124:2]; [41:124]; [90:232-234] \\
\hline Turkish & sevgi otu & & [“Love plant”] & [41:124]; [90:232-234] \\
\hline Ukrainian & lubovyća & любовица & [“Love plant”] & [12:162] \\
\hline
\end{tabular}

Table 4: D. Magic and witchcraft: D1. Black magic, sorcery, witchcraft; D2. Evil supernatural agents - Satan, devil, genie, monster, dragon; D3. White magic, good luck, talisman, dolls. 


\begin{tabular}{|c|c|c|c|c|}
\hline $\begin{array}{l}\text { Language/ } \\
\text { Subcategory }\end{array}$ & Name & $\begin{array}{l}\text { Ethnic } \\
\text { Transcription }\end{array}$ & Meaning & Selected References \\
\hline \multicolumn{5}{|l|}{ D1 } \\
\hline Dutch & toverwortel, tooverwortel & & [“Magic root”] & [146:940]; [158:255]; [159:333]; [28:71]; [105:35] \\
\hline Dutch & heksenkruid & & [“Witches' herb”] & [146:940]; [105:35] \\
\hline Dutch & heksen loverwortel & & [“Witches' love root"] & [28:71]; [31:45] \\
\hline English & sorcerer's root & & & [12:166]; [109:70] \\
\hline English & enchanter's nightshade & & & [54:354] \\
\hline English & witches' herb & & & [149:316] \\
\hline Estonian & Nöiajuua & & [“Magic root”] & Dainius Razauskas (Pers. Com.12.3.19). \\
\hline French & $\begin{array}{l}\text { herbe aux, } \\
\text { magicien, herbe des } \\
\text { magiciens }\end{array}$ & & [“Magician's plant"] & [160:91]; [28:71]; [31:43]; [29:336] \\
\hline German & Hexenkraut & & [“Witches' herb"] & [83:258]; [119:137]; [28:71] \\
\hline German & $\begin{array}{l}\text { zauberwurzel, } \\
\text { zauberwurz }\end{array}$ & & [“Magic root"] & [75:229]; [134, III:53]; [31:42]; [30:335]; [114:15]; [28:71]; [80:19] \\
\hline Hungarian & Varázsgyökér & & ["Magic/miracle root"] & {$[161: 151]$} \\
\hline Serbian & [skocelj / skočac] & $\begin{array}{l}\text { Скоцељ / } \\
\text { Скочац }\end{array}$ & $\begin{array}{l}\text { The word "skakati" } \\
\text { means jump, leap. } \\
\text { Probably related to } \\
\text { beliefs in a very "alive," } \\
\text { restless, and troublous } \\
\text { root, especially when } \\
\text { pulled out from the soil / } \\
\text { of "skocelj"; skočac" } \\
\text { means one who jumps. }\end{array}$ & [71:20] \\
\hline Russian & [koldunowa trawa] & $\begin{array}{l}\text { кольдунова } \\
\text { трава }\end{array}$ & [“Sorcerer's root”] & [83:259]; [162:1129] \\
\hline \multicolumn{5}{|l|}{ D2 } \\
\hline Arabic & bēọ el-g்ūl & 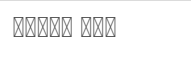 & [“Monster's eggs"] & $\begin{array}{l}\text { [163:34] (North Africa); [129:167]; [92:26]; AGK pers. obs. } \\
\text { (Palestine) }\end{array}$ \\
\hline Arabic & beiḍ el- ğinn & 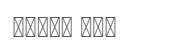 & [“Genie's eggs"] & [164:114]; [165, II:261] (Palestine). \\
\hline Arabic & bayḍ al- gūl, bayḍ el- gūūl & 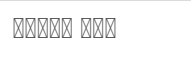 & ["Goula's (witches') eggs"] & [166:47] (Morocco) \\
\hline Arabic & xawx el-ğinn & 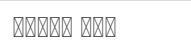 & [“The Jin's Peach”] & [167] (Lebanon) \\
\hline Arabic & luffāḥ el-ğinn & 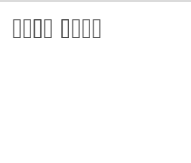 & $\begin{array}{l}\text { [“The burning (or } \\
\text { emitting a good odour) } \\
\text { fruit or of the Genie" }\end{array}$ & [129:167]; [92:26] (North Africa) \\
\hline Arabic & tuffāḥ il-mağal & 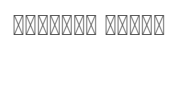 & $\begin{array}{l}\text { Probably derivative } \\
\text { of Tuffāḥ il Mağann }\end{array}$ & [168, I:250] (Palestine, Gaza area) \\
\hline Arabic & tuffāḥ il-gūūla & Q & [“Goula's apple”] & [163:34] (Morocco) \\
\hline Arabic & $\begin{array}{l}\text { [tuffāḥ al- ğinn, } \\
\text { Spelling variants: } \\
\text { tuffāhh al- } \\
\text { mağânîn, tuffāḥ al- } \\
\text { mağan, } \\
\text { tuffāḥat al -ğinn] }\end{array}$ & 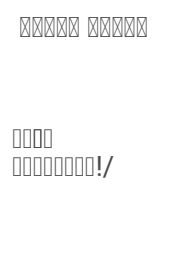 & $\begin{array}{l}\text { ["'Apple of the Genie/ } \\
\text { Apple of the Genies"] }\end{array}$ & $\begin{array}{l}\text { [84:351] (Andalusia, } 6-7^{\text {th }} \text { c.); [87:54] (Arabia, } 10-11^{\text {th }} \text { c.); [169, } \\
\text { Ill:21]; [170:577] (Palestine); } 164: 114] ;[171: 87] ;[172: 248] \text { (Moor } \\
\text { Spain); [41:121]; [89:299] (Palestine); [90:115]; [173:73] } \\
\text { (Palestine). }\end{array}$ \\
\hline
\end{tabular}




\begin{tabular}{|c|c|c|c|c|}
\hline & & 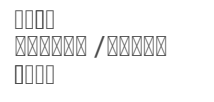 & & \\
\hline Arabic & [tuffāḥ eš-šayțān] & & [“Apple of Satan"] & [174:587] (Palestine); AGK Pers. Obs. (Palestine) \\
\hline Czech & Divelsappl & & [“Devil's apple"] & [29:346] \\
\hline Dutch & Duivelsplant & & [“Devil's plant”] & {$[29: 346]$} \\
\hline [Dutch & appeldragend & & [“Dragon's apple”] & [83:258]; [28:71] \\
\hline Dutch & Duivelsete & & [“Devil's food"] & [29:3346] \\
\hline English & devil's apple & & & [175:209]; [159:332]; [176:24]; [179:64] \\
\hline English & devil's food & & & [180:60]; [181:85] \\
\hline English & dragon's doll & & & [149:316]; [109:70] \\
\hline English & Satan's testicle & & & [149:316] \\
\hline German & Drachenpuppe & & [“Dragon's puppet"] & [30.321]. \\
\hline German & Satansapfel & & [“Satan's apple”] & [151:693]; [81:23] \\
\hline German & Teufelsapfel & & [“Devil's apple"] & [134, III :53]; [28]; [31:42]; [30:335] \\
\hline German & unholdwurz & & [“Demon's root”] & [134, III: 53]; [28:71]; [31:42]; [30:335] \\
\hline German & Unholdkraut & & [“Demon's herb”] & [75:229]; [28:71] \\
\hline German & wichtelmännchen & & [“Imp”] & [120:113]; [31:42]; [30:337] \\
\hline Greek & [kalánthropos] & 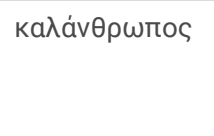 & $\begin{array}{l}\text { [“Goblin”] (because their } \\
\text { root looks like } \\
\text { Kalikántzaros, the } \\
\text { goblin in Greek folklore) }\end{array}$ & [177] \\
\hline Hungarian & Ördögalma & & [“Devil's apple"] & [178] \\
\hline Polish & Czartawa & & $\begin{array}{l}\text { [“The demon } \\
\text { flower"] }\end{array}$ & [12:164] \\
\hline Turkish & cinelması & & [“Ghost's apple"] & [73:107]; [41:124] \\
\hline Turkish & şeytan şalgamı & & ["Satan's turnip"] & [41:12] \\
\hline \multicolumn{5}{|l|}{ D3 } \\
\hline French & plante qui chante & & $\begin{array}{l}\text { [“Singing plant”] } \\
\text { (see text) }\end{array}$ & [28:71] \\
\hline German & $\begin{array}{l}\text { geldmännlein , } \\
\text { geldmännchen }\end{array}$ & & $\begin{array}{l}\text { [“Little money- } \\
\text { man”]/money mannikin }\end{array}$ & [83:258]; [114:15]; [29, II:343] \\
\hline German & $\begin{array}{l}\text { glücksmännlein, } \\
\text { glücksmännchen }\end{array}$ & & $\begin{array}{l}\text { [“Little } \\
\text { fortune-man/good luck } \\
\text { manikin”] }\end{array}$ & [182:88]; [120:113]; [29, II:343] \\
\hline German & Hausväterchen & & [“Little house father”] & 11 \\
\hline German & Hinzelmannchen & & [“Gnome”] & \\
\hline
\end{tabular}


Table 5: E. Pulling-out ceremonies: E1. Screaming, groaning, and voices; E2. Use of a dog; E3. Shining and lights. 


\begin{tabular}{|c|c|c|c|c|}
\hline $\begin{array}{l}\text { Language/ } \\
\text { Subcategory }\end{array}$ & Name & $\begin{array}{l}\text { Ethnic } \\
\text { Transcription }\end{array}$ & Meaning & Selected References \\
\hline \multicolumn{5}{|l|}{ E1 } \\
\hline French & plante qui crie & & [“The Screaming plant”] & [28:71] \\
\hline \multirow[t]{2}{*}{ Polish } & krzykaiec, & & [“Screamer"]/[“Female & {$[12: 164]$} \\
\hline & krykwa & & Screamer"] & \\
\hline Polish & $\begin{array}{l}\text { pokrzyk, } \\
\text { pokrzyk, } \\
\text { białgłwi, } \\
\text { pokrzyk samiec }\end{array}$ & & $\begin{array}{l}\text { ["The screamer"]/["The female's scream, The } \\
\text { Screaming Female"]/["The male's scream, the } \\
\text { screaming male"] }\end{array}$ & [12:166]; [182:180]. \\
\hline Polish & $\begin{array}{l}\text { pokrzyk ziele, } \\
\text { pokrzykowe } \\
\text { ziele }\end{array}$ & & [“The screamer herb”] & [83:259]; [162:1129]; [12:164] \\
\hline Russian & [pevenka trava] & $\begin{array}{l}\text { певенька } \\
\text { трава }\end{array}$ & ["The screaming herb"] & {$[63, \mathrm{I}: 23$ ]; [27:19] } \\
\hline Serbian & [pokrik] & Покрик & $\begin{array}{l}\text { The root of the word is "krik" meaning scream or cry. } \\
\text { It is believed that when the root is pulled out, it } \\
\text { screams and cries terribly, resembling a baby's cry. }\end{array}$ & [70:291] \\
\hline Turkish & hüngürük kökü & & $\begin{array}{l}\text { ["Sobbing root"] (It is believed that it sobs when } \\
\text { pulled out from the earth.) }\end{array}$ & [73:107]; [28:71]; [41:122,124]; [124:2] \\
\hline \multicolumn{5}{|l|}{ E2 } \\
\hline Arabic & [qātil al-kalb] & 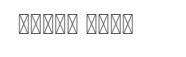 & [“Dog's killer”] & [125:624-625] (Andalusia, $13^{\text {th }}$ c.). \\
\hline Dagestani & xlapuleb xer & & ["Barking grass", "grass [causing] barking”] & [184:1486] cited by [102:250] \\
\hline Dutch & $\begin{array}{l}\text { hondsappel, } \\
\text { hundappel, } \\
\text { hunderapfel }\end{array}$ & & [“Dog's apple”] & [151:42]; [28:71]; [31:45]; [102:35] \\
\hline Farsi & [sag-kanak] & 峸讴 & [“Dog uprooter”] & [95:691]; [185:200]; [186, III:366] \\
\hline & & & (=Dog killer) & \\
\hline Farsi & [sag-kuš] & 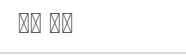 & [“Dog killer"] (= dog slayer) & [100:106]; [101:152] \\
\hline Farsi & $\begin{array}{l}\text { [sag-šikan, } \\
\text { sag-shekan] }\end{array}$ & 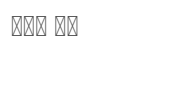 & [“Dog breaker”] & [100:106]; [101:152] \\
\hline French & $\begin{array}{l}\text { pomme de } \\
\text { chien }\end{array}$ & & [“Dog's apple"] & [112:225]; [28:71]; [3:44]; [29:346]; [113:8] \\
\hline German & $\begin{array}{l}\text { hunds apfel, } \\
\text { hunds } \\
\text { apfelwurzel }\end{array}$ & & [“Dog's apple”] & $\begin{array}{l}\text { [83:258]; [118:335]; [135:23]; [119:137]; } \\
\text { [134:53]; [28:71]; [114:15]; [81:23] }\end{array}$ \\
\hline Greek & [mala canina] & $\mu a ́ \lambda a$ kaviva & ["Dog's apple"] & {$[45: 4,75]$} \\
\hline Italian & mela canina & & ["Dog's apple"] & [65] (Tuscany); [28:71] \\
\hline Italian & poma di cane & & [“Dog's apple"] & [133:184]; [77:333] \\
\hline Italian & mala canina & & [“Dog's apple"] & [133:184] \\
\hline Turkish & köpek elması & & [“Dog's apple"] & [73:107]; [187:15]; [188:23] \\
\hline
\end{tabular}

Page 35/42 


\begin{tabular}{|c|c|c|c|c|}
\hline Turkish & köpek otu & & [“Dog's plant"] & [73:107]; [187:15-17]; [188:23] \\
\hline Turkish & köpektaşağı & & [“Dog's testicle"] & [41:124]; [123:21] \\
\hline \multicolumn{5}{|l|}{ E3 } \\
\hline Arabic & $\begin{array}{l}{[a l-y a b r u ̄ h ̣ \text { al- }} \\
\text { waqqād] }\end{array}$ & 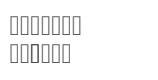 & ["The burning mandrake"] & [132:14] \\
\hline Arabic & [sirāğ al-qutrub] & 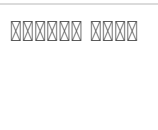 & $\begin{array}{l}\text { [“Devil's candle" or "firefly candle"] } \\
\text { (see text) }\end{array}$ & $\begin{array}{l}\text { [87:54] (Arabia, } 10-11^{\text {th }} \text { c.); [122:3]; [138:246] } \\
\text { (Andalusia, } 13^{\text {th }} \text { c.); [88:14]; [187, I:49]; } \\
\text { [190:250]; [191, 891; No.246]; [28:71]; [41:121] }\end{array}$ \\
\hline Russian & $\begin{array}{l}\text { chortovaja } \\
\text { svecha }\end{array}$ & $\begin{array}{l}\text { чёртовая } \\
\text { свеча }\end{array}$ & $\begin{array}{l}\text { ["Devil's candle"]; the Avarians believe that the } \\
\text { mandragora emits light at night }\end{array}$ & [192:143] \\
\hline
\end{tabular}

Table 6. F. Gallows and hanging: F1. Plant originated from human semen, urine under gallows; F2. Creation of Adam. 


\begin{tabular}{|c|c|c|c|c|}
\hline \multicolumn{5}{|l|}{ F1 } \\
\hline Dutch & galgejong, galgenjong & & $\begin{array}{l}\text { [“Gallows' } \\
\text { youngling"] }\end{array}$ & [31:45]; [28:71]; [102:35] \\
\hline Dutch & galgenmann, galgemannekens, galgenmanntje & & $\begin{array}{l}{[“ G a l l o w s '} \\
\text { man"] }\end{array}$ & [107:63]; [102:35] \\
\hline Dutch & Pisdiefje & & ["Piss thief”] & [159:333]; [31:45] \\
\hline Dutch & pisduiveltje & & $\begin{array}{l}\text { [“Little piss } \\
\text { devil”] }\end{array}$ & [159:333]; [31:45] \\
\hline \multirow[t]{2}{*}{ French } & Madaglorie & & ["Hand of & [56:66]; [28:71]; [31:43]; [30:332]; [29:346] \\
\hline & $\begin{array}{l}\text { Spelling variations: magloire, madagloire, main- } \\
\text { de-gloire, main degloire, maindeglorie, } \\
\text { mandagloire, mandegloire, main de gore }\end{array}$ & & (see text) & \\
\hline German & armesünderblume & & $\begin{array}{l}\text { ["Poor sinner's } \\
\text { flower"] }\end{array}$ & [30:330]; [80:19]; [81:23] \\
\hline German & Folterknechtswurzel & & $\begin{array}{l}{[\text { ["Torturer's }} \\
\text { root”] }\end{array}$ & [30:331]; [114:15]; [80:19]; [81:23] \\
\hline German & folterwurzel & & $\begin{array}{l}{[\text { ["Torturer's }} \\
\text { herb"] }\end{array}$ & {$[27: 344]$} \\
\hline German & galgenwurz & & $\begin{array}{l}{[“ G a l l o w s '} \\
\text { root"] }\end{array}$ & [81:23] \\
\hline German & $\begin{array}{l}\text { galgenmännlein, } \\
\text { galgenmännchen }\end{array}$ & & $\begin{array}{l}\text { [“Little gallows, } \\
\text { man," Gallows' } \\
\text { mannikin"] }\end{array}$ & [83:258]; [119:137]; [193:passim]; [134:53]; [114;15] \\
\hline German & henkerswurz, henkerswurzel & & $\begin{array}{l}\text { [“Executioner's } \\
\text { Root"] }\end{array}$ & [114]; [27]; [81]. \\
\hline German & pissdiebchen, pissedieb & & ["Piss thief"] & $\begin{array}{l}\text { [119:137]; } \\
\text { 75:229]; [134, III:53]; [28:71]; [31:42]; [30:334]; [81:32] }\end{array}$ \\
\hline Icelandic & thjófarót & & [“Thief's root”] & [194:44]; [195:60] \\
\hline Italian & mano di gloria & & $\begin{array}{l}{[\text { ["Hand of }} \\
\text { glory”] }\end{array}$ & [65] (Sicily) \\
\hline \multicolumn{5}{|l|}{ F2 } \\
\hline Russian & [adamowa golowa] & $\begin{array}{l}\text { адамова } \\
\text { глава }\end{array}$ & $\begin{array}{l}\text { [“Adam's } \\
\text { head"] }\end{array}$ & [63:I:1458]; [162:1129]; [196:335]; [197:203] \\
\hline Serbian & Adamova glava & $\begin{array}{l}\text { адамова } \\
\text { глава }\end{array}$ & $\begin{array}{l}\text { Adam's head } \\
\text { ("glava" means } \\
\text { head) }\end{array}$ & [70:291] \\
\hline Turkish & âdemotu & & ["Adam's plant"] & [73:107]; [123:21] \\
\hline
\end{tabular}

Table 7. G: G1. Relation to historical and mythological characters: King Solomon, Circe, and Prometheus; G2. Elephant. 


\begin{tabular}{|c|c|c|c|c|}
\hline Language & Name & Ethnic Transcription & Meaning & Selected References \\
\hline \multicolumn{5}{|l|}{ G1 } \\
\hline Arabic & [šajarat Suleimān] & 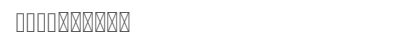 & [" (King) Solomon's tree"] & [99] \\
\hline \multirow[t]{2}{*}{ Armenian } & [sołomon- & 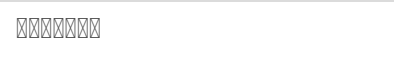 & Literally ["Solomon's tree”] & {$[198: 97]$ (15 ${ }^{\text {th }}$ c.); [100:106]; [101:152] } \\
\hline & imastunicar] & & & \\
\hline English & herb of Circe & & & [199:224]; [29, II:336]; [109:70] \\
\hline English & herb of Prometheus & & & [200:496]; [201:121] \\
\hline French & circée & & [“Circe”] & {$[29: 336]$} \\
\hline German & prometheuskraut & & [“Prometheus herb] & {$[31 \cdot 42]$} \\
\hline German & zauberpflanze der circe & & [“Circe's magic plant] & [28:71]; [31:42] \\
\hline \multirow[t]{3}{*}{ Greek } & kirkéa & Кıрка囚оv / КıркаХа / Аıрка囚а & [“Circe”] & {$[45: 4,75]$} \\
\hline & (Speliing variants: kirkéon, & & & \\
\hline & dirkéa) & & & \\
\hline \multicolumn{5}{|l|}{ G2 } \\
\hline English & elephant ear & & See text & [202:249] \\
\hline
\end{tabular}

Table 8: Non-classified names: 


\begin{tabular}{|c|c|c|c|c|}
\hline Language & Name & $\begin{array}{l}\text { Ethnic } \\
\text { Transcription }\end{array}$ & Meaning & $\begin{array}{l}\text { Selected } \\
\text { References }\end{array}$ \\
\hline Arabic & [/abbāḥ] & $\begin{array}{l}\text { Luffậh) } \\
\text { Luariant of }\end{array}$ & [“Makes a man brave”] (A hint for a potent man?) & $\begin{array}{l}{[86: 107] \text { (Arabia, } 9^{\text {th }} \text { c.); }[85 \text {, }} \\
\text { II: } 449,774] \text { (Andalusia, } 11^{\text {th }} \\
\text { c.). }\end{array}$ \\
\hline Arabic & [mag்d] & & & $\begin{array}{l}{[86: 107] \text { (Arabia, } 9^{\text {th }} \text { c.); }} \\
{\left[85, \text { II:774] (Andalusia, } 11^{\text {th }}\right.} \\
\text { c.); }[140: 1219]\end{array}$ \\
\hline Arabic & [šuğğāđ] & प्राप्रा & $\begin{array}{l}\text { [“Brave"] (A hint for a } \\
\text { potent man?) }\end{array}$ & $\begin{array}{l}\text { [168, I: } 250] ;[164: 114] \\
\text { (Palestine) }\end{array}$ \\
\hline Basque & $\begin{array}{l}\text { urrillo, urrilo, } \\
\text { urriloa ,urriola }\end{array}$ & & & [66] \\
\hline Berber & [tāryāl, taralya] & & & $\begin{array}{l}{[85,11: 774] \text { (Andalusia, } 9-11^{\text {th }}} \\
\text { C.); [203:213]; [204:257] } \\
\text { (Morocco). }\end{array}$ \\
\hline Berber & $\begin{array}{l}{[\text { habb al『ilb, }} \\
\text { ḩabb atta冈liff] }\end{array}$ & & "wild" seeds & $\begin{array}{l}{[85,11: 774] \text { (Andalusia, } 9-11^{\text {th }}} \\
\text { c.) }\end{array}$ \\
\hline Catalan & albalarosa & & & {$[84: 351]$} \\
\hline Chinese & [재] & qie shen shu & $\begin{array}{l}\text { Qie } \otimes \text { in Chinese is } \\
\text { Solanaceae (refers to plants in this family), } \otimes \text { is suggesting a fat } \\
\text { root or stem } \\
\text { underground, like that of Ginseng }\end{array}$ & [205] \\
\hline Greek & [diámorfos] & $\delta ı \dot{\mu} \mu \rho \varphi о \varsigma$ & [“Double-formed; endued with various forms"] & {$[45: 4,75]$} \\
\hline Greek & [emionás] & \uıvác & $\begin{array}{l}\text { [“Mule's plant”] (may be due to the use of mules to eradicate the } \\
\text { plant?) }\end{array}$ & {$[45: 4,75]$} \\
\hline Greek & $\begin{array}{l}\text { [kalánthropos]/ } \\
\text { [kalanthropáki] }\end{array}$ & 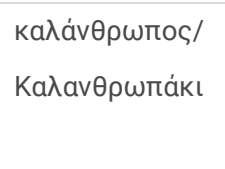 & $\begin{array}{l}\text { [“Good man"] (euphemistic name), } \\
\text { [diminutive } \\
\text { for “kalánthropos"] }\end{array}$ & $\begin{array}{l}\text { [121:357] (Cyprus); [62:600]; } \\
\text { [58]; [206:78-79]; [59:429] }\end{array}$ \\
\hline Greek & $\begin{array}{l}\text { [kalanthropári]/ } \\
\text { [kalanthropárin] }\end{array}$ & 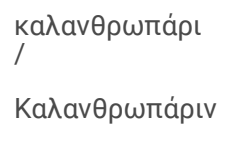 & $\begin{array}{l}\text { [“Good-man shaped"] (euphemistic name); [diminutive for } \\
\text { "kalánthropos"]/ } \\
\text { [“Good -man (shaped)”] [euphemistic name); [diminutive for } \\
\text { "kalánthropos"] }\end{array}$ & $\begin{array}{l}\text { [121:357] (Cyprus); [206:78- } \\
\text { 79] (Cyprus); [62:600]; [58:509] } \\
\text { (Greece) }\end{array}$ \\
\hline Greek & [kaláthreptos] & 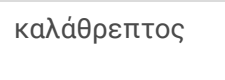 & $\begin{array}{l}\text { [“Well-fed”] (name probably based on the plant's fat roots (see } \\
\text { also the name arkánthropos above) }\end{array}$ & [206:78-79] \\
\hline Greek & [kaláthrepos] & 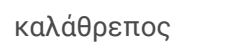 & Corrupted from "kalánthropos" or "kaláthreptos" & [59:436] \\
\hline Greek & [skalánthropos] & 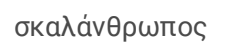 & [“Good man”; “Wooden man”] & [59:431] \\
\hline Greek & [tátoulas] & tátouגas & $\begin{array}{l}\text { Besides mandrake, also Datura stramonium, Solanum } \\
\text { nigrum and Atropa belladonna. Seems to be a corrupted form of } \\
\text { "Datura." }\end{array}$ & [59:431] \\
\hline Latin & aperium & & & {$[45: 4,75]$} \\
\hline Polish & nasik & & May be related to the seeds? & {$[12: 164]$} \\
\hline Serbian & [dliskva] & Длисква & $\begin{array}{l}\text { Word without meaning; "liska" means leaf; probably "d" as "do" } \\
\text { meaning near; thus the word could refer to the importance of the } \\
\text { part near to the leaf, i.e the root, since mandrake is stemless, or } \\
\text { the importance of a fruit. }\end{array}$ & {$[71: 20]$} \\
\hline
\end{tabular}




\begin{tabular}{|c|c|c|c|}
\hline Spanish & $\begin{array}{l}\text { vilanera, } \\
\text { vinanera }\end{array}$ & [“Vinegar-taste plant”] & [66] \\
\hline Spanish & vinagrera & [“Vinegar-taste plant”] & {$[66]$} \\
\hline $\begin{array}{l}\text { Syriac } \\
\text { (Eastern } \\
\text { Aramaic) }\end{array}$ & bnat ganē & A name for the mandrake's fruit & [186, III:193] \\
\hline Turkmenian & selmelek & Local name & [207:176] \\
\hline Turkish & at elması & [“Horse's apple”] & [73:107]; [123:21] \\
\hline Turkish & bendavleo & & [41:124] (North Cyprus) \\
\hline Turkish & hacılar otu & [“Pilgrim's plant”] & [123:21]; [28:71] \\
\hline Turkish & hacı otu & [“Pilgrim's plant”] & [73:107] \\
\hline
\end{tabular}

Table 9: Mandrake name distribution according to languages and categories

: 296 vernacular names for the plant in 42 different languages 


\begin{tabular}{|c|c|c|c|c|c|c|c|c|c|c|c|c|c|c|c|c|c|c|c|c|c|}
\hline Category & A & & & B & & & C & & & D & & & $E$ & & & $\mathbf{F}$ & & G & & NC & Total \\
\hline Subcategory/ & $\mathrm{A} 1$ & A2 & A3 & B1 & B2 & B3 & C1 & $\mathrm{C} 2$ & C3 & D1 & D2 & D3 & E1 & E2 & E3 & $\mathrm{F} 1$ & F2 & G1 & G2 & NC & \\
\hline \multicolumn{22}{|l|}{ Language } \\
\hline Albanian & 1 & & & & & & & & & & & & & & & & & & & & 1 \\
\hline Arabic & & & 3 & 1 & 3 & 3 & 2 & & 4 & & 9 & & & 1 & 2 & & & 1 & & 3 & 32 \\
\hline Aramaic & & & 1 & 1 & & & & & & & & & & & & & & & & & 2 \\
\hline Armenian & 1 & & & & 1 & & 1 & & & & & & & & & & & 1 & & & 4 \\
\hline Basque & & & & & & & & & & & & & & & & & & & & 1 & 1 \\
\hline Bengali & & & 1 & & & & & & & & & & & & & & & & & & 1 \\
\hline Berber & & & & & & & & & & & & & & & & & & & & 2 & 2 \\
\hline Bulgarian & 1 & & & & & & & & & & & & & & & & & & & & 1 \\
\hline Catalan & 1 & & & & & & & & & & & & & & & & & & & 1 & 2 \\
\hline Chinese & & & & & & & & & & & & & & & & & & & & 1 & 1 \\
\hline Corsican & 1 & & & & & & & & & & & & & & & & & & & & 1 \\
\hline Czech & & & & 2 & & & & & & & 1 & & & & & & & & & & 3 \\
\hline Dagestani & & & & & & & & & & & & & & 1 & & & & & & & 1 \\
\hline Danish & & 1 & & 1 & & & & & 1 & & & & & & & & & & & & 3 \\
\hline Dutch & 2 & 2 & & 5 & & & & 3 & & 3 & 3 & & & 1 & & 4 & & & & & 23 \\
\hline English & 1 & & & 3 & & & & 3 & & 3 & 4 & & & & & & & 2 & 1 & & 17 \\
\hline Estonian & & & & & & & & & & 1 & & & & & & & & & & & 1 \\
\hline Farsi & & & 1 & 1 & 1 & & & & 1 & & & & & 3 & & & & & & & 7 \\
\hline Finnish & & 1 & & & & & & & 1 & & & & & & & & & & & & 2 \\
\hline French & 1 & & & 2 & & 2 & & & & 1 & & 1 & 1 & 1 & & 1 & & 1 & & & 11 \\
\hline Gaelic & & & & & & & & 1 & & & & & & & & & & & & & 1 \\
\hline Georgian & 1 & & & & & & & & & & & & & & & & & & & & 1 \\
\hline German & & 1 & & 7 & & 3 & 1 & 5 & 3 & 2 & 6 & 4 & & 1 & & 7 & & 2 & & & 42 \\
\hline German, Old & & & & & & & 1 & 1 & 1 & & & & & & & & & & & & 3 \\
\hline Greek & 2 & & & 3 & 5 & 5 & 2 & 6 & 1 & & 1 & & & 1 & & & & 1 & & 8 & 35 \\
\hline Hebrew & & & & & & & & & 1 & & & & & & & & & & & & 1 \\
\hline Hungarian & 1 & & & & & & & 1 & & 1 & 1 & & & & & & & & & & 4 \\
\hline Icelandic & & & & & & & & & & & & & & & & 1 & & & & & 1 \\
\hline Italian & 1 & & & & & & & & & & & & & 3 & & 1 & & & & & 5 \\
\hline Latin & & & & 2 & & 3 & & & & & & & & & & & & & & 1 & 6 \\
\hline Norwegian & & 1 & & & & & & & & & & & & & & & & & & & 1 \\
\hline Polish & 1 & & & 1 & & & & & & & 1 & & 3 & & & & & & & 1 & 7 \\
\hline Portuguese & 1 & & & & & & & & & & & & & & & & & & & & 1 \\
\hline Russian & 1 & & & & & & & & & 1 & & & 1 & & 1 & & 1 & & & & 5 \\
\hline Serbian & 3 & 1 & & & 5 & 1 & 1 & & & 1 & & & 1 & & & & 1 & & & 1 & 15 \\
\hline Slovak & & & & & & 1 & & & & & & & & & & & & & & & 1 \\
\hline Spanish & 2 & & & & 1 & 7 & & 1 & & & & & & & & & & & & 2 & 13 \\
\hline Syriac & & & & & & & & & & & & & & & & & & & & 1 & 1 \\
\hline Swedish & & 2 & & & & & & & & & & & & & & & & & & & 2 \\
\hline Turkish & 1 & & 2 & 4 & 3 & 4 & 3 & & 3 & & 2 & & 1 & 3 & & & 1 & & & 4 & 31 \\
\hline Turkmenian/ Russian & 1 & & & & & & & & & & & & & & & & & & & 1 & 2 \\
\hline
\end{tabular}




8

33

$\begin{array}{llllll}19 & 29 & 11 & 21 & 17 & 13\end{array}$

28

\section{Figures}

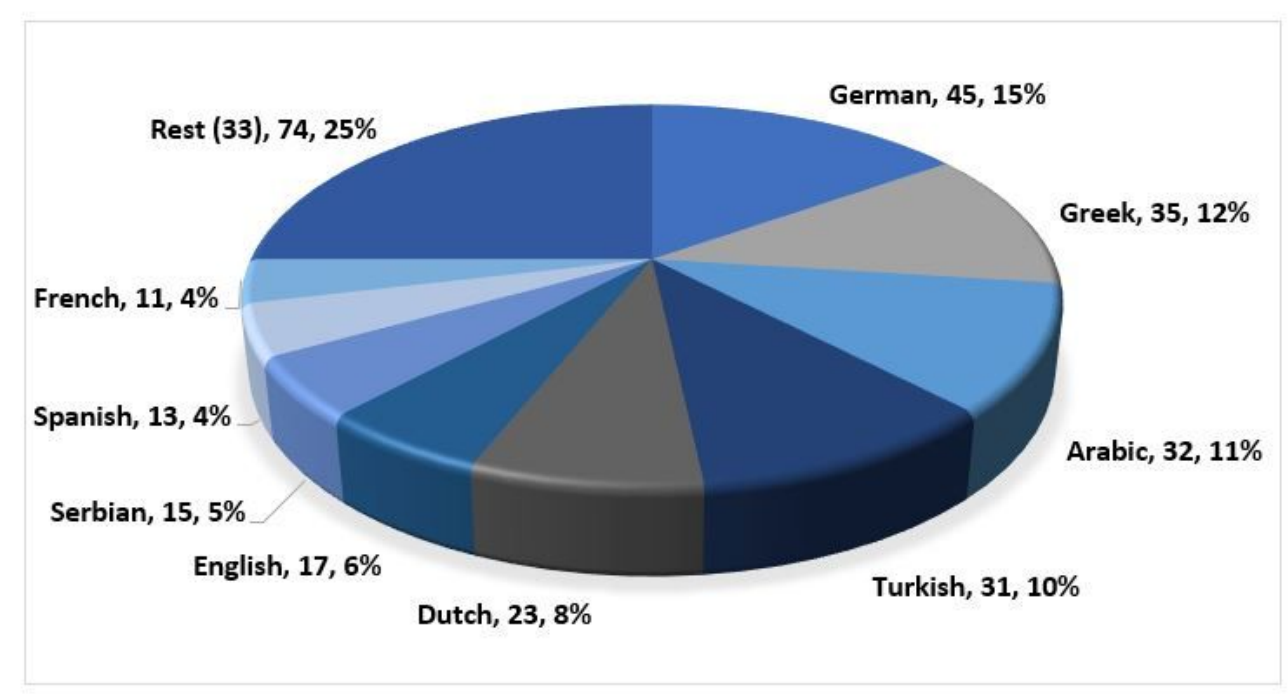

Figure 1

Languages which comprise more than ten vernacular names for mandrake; number of names and percentages.

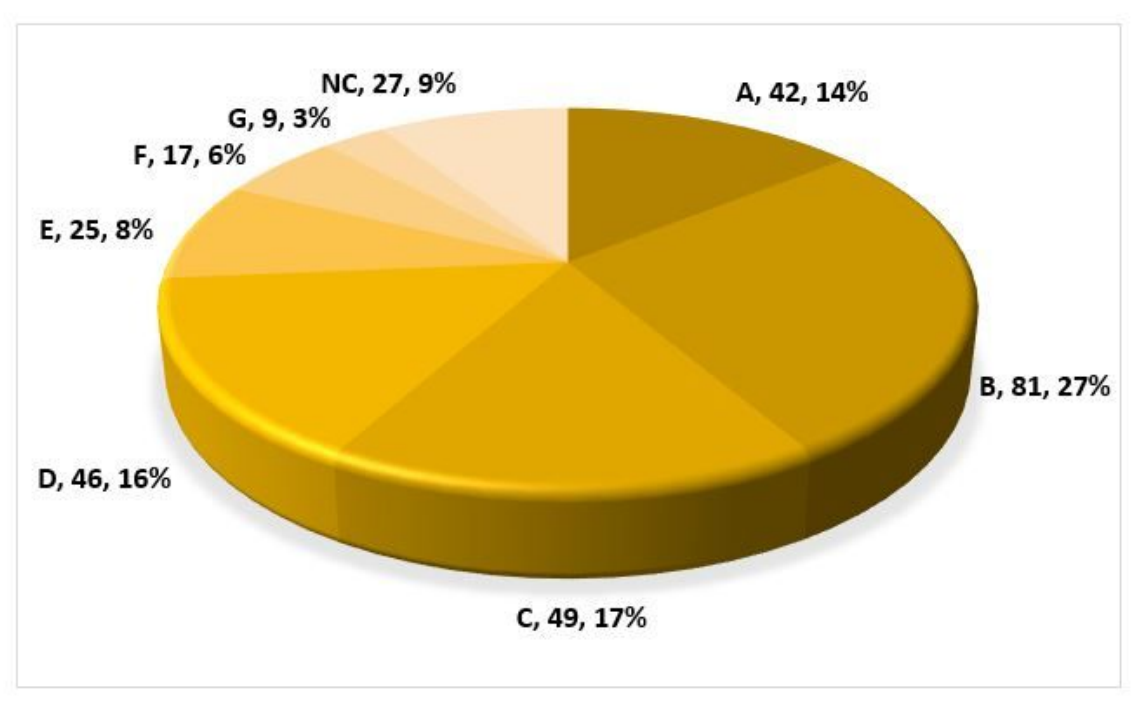

\section{Figure 2}

Distribution of names in main categories 